\title{
SPATIO-TEMPORAL DISTRIBUTIONS AND TRENDS OF AEROSOL PARAMETERS OVER PAKISTAN USING REMOTE SENSING
}

\author{
TARIQ, S.* - UL-HAQ, Z. - MAHMOOD, K. - RANA, A. D. \\ Remote Sensing and GIS Group, Department of Space Science, University of the Punjab, New- \\ Campus, Lahore-54590, Pakistan \\ *Corresponding author \\ e-mail: salmantariq_pu@yahoo.com; phone: +92-300-884-4797 \\ (Received $18^{\text {th }}$ Oct 2017; accepted $12^{\text {th }}$ Feb 2018)
}

\begin{abstract}
Aerosols play a major role in atmospheric solar radiation budget, air quality degradation and climate change. In order to accurately evaluate aerosols effects, we require an in-depth knowledge of spatio-temporal distributions of their parameters. The focus of this paper is to analyze spatio-temporal distributions and trends of aerosol parameters over Pakistan. In present study, Terra-MODIS data have been used during April 2000-March 2014 to analyze AOD (550 nm), Angstrom exponent (470-660) $\left(\mathrm{AE}_{470-660}\right)$, small mode fraction (SMF) and mass concentration (MC). Values of coefficient of determination $\left(R^{2}\right)$ between Terra-AOD and AERONET-AOD are found to be 0.718 and 0.745 for Lahore and Karachi respectively. Terra-AOD has also been compared with other satellite-based observations obtained from Aqua, MISR and SeaWiFS. A notable spatial variability in mean annual Terra-AOD values $(0.15-0.87)$ has been observed with high values ( 0.8) over northeastern and southern Pakistan. $\mathrm{AE}_{470-660}$ ranges from 0.56 to 1.44 showing high values (greater than 0.8 ) over northern Pakistan and relatively low values (less than 0.8 ) over southern Pakistan. MC is found to be in the range from $7.6 \mu \mathrm{g} / \mathrm{cm}^{2}$ to 56.2 $\mu \mathrm{g} / \mathrm{cm}^{2}$ with spatial distribution quite similar to AOD. Overall mean values of $\mathrm{AOD}, \mathrm{AE}$ 470-660, $\mathrm{SMF}$ and $\mathrm{MC}$ are found to be $0.43 \pm 0.16,0.68 \pm 0.06,0.11 \pm 0.05$ and $28.2 \pm 9.71 \mu \mathrm{g} / \mathrm{cm}^{2}$ respectively.
\end{abstract}

Keywords: AOD, Angstrom exponent, SeaWiFS, small mode fraction

\section{Introduction}

Aerosols contribute to atmospheric climate forcing, air quality degradation, hydrological cycle and precipitation processes (Charlson et al., 1992; Ramanathan et al., 2001; Lohmann and Feichter, 2005; Kosmopoulos et al., 2008). They are also recognized as a major factor that affects the global climate change (IPCC, 2007). It is well established fact that aerosol particles affect the climate directly by scattering and absorption of incoming solar radiation and indirectly by serving as cloud condensation nuclei (Forster et al., 2007; Carslaw et al., 2010; Arneth, A. et al., 2010; Mahowald, 2011). All types of aerosols except black carbon cause cooling at top of the atmosphere and reduce the warming caused by greenhouse gases (Forster et al., 2007). In order to achieve better air quality, reduction in anthropogenic emissions may weaken this useful effect (Arneth, et al., 2009; Mickley et al., 2012; Makkonen et al., 2012).

Aerosols also have harmful effects on human health and ecosystem services (Smart et al., 2011). Long term and detailed studies have shown a significant relationship between aerosol concentrations and human health. The studies have been conducted over various regions of the world and the results have established considerable effects on human health due to aerosols. Due to human health and environmental implications, knowledge of properties and spatio-temporal distribution of aerosols is essential.

Insufficient observations of aerosols have caused dominant uncertainties in the climate modeling (Koukouli et al., 2010; Bennouna et al., 2013). In order to accurately 
evaluate the climate forcing, an in-depth knowledge of optical and physical properties of aerosols at different spatial and temporal scales is required (He et al., 2012; Luo et al., 2014). Different types of aerosols affect the sign and magnitude of climate forcing distinctively (Kaskaoutis et al., 2007). For instance, black carbon aerosols emitted from biomass burning cause positive climate forcing (Jacobson, 2001; Penner et al., 2003), while mineral dust particles show negative forcing at shortwave by scattering the solar radiations (Sokolik and Toon, 1996).

Although ground based observations provide more detailed and authentic information about the atmospheric aerosols, they do not have large-scale spatial coverage (Tariq and Ali, 2015; Tariq, 2017). Aerosol concentrations are extremely variable in both time and space. Satellite remote sensing has the ability to monitor aerosols burden and their properties at large scales (Tariq and Ali, 2015). A number of studies have discussed spatio-temporal variability and trends of aerosols concentrations over the study region and its adjoining areas of Indian subcontinent (Prasad et al., 2006; Alam et al., 2011; Dani et al., 2012; Gupta et al., 2013; Sreekanth, 2013). Prasad et al. (2006) and Dani et al. (2012) found a sharp increase in aerosol optical depth (AOD) over Indian region, due to enhanced urbanization and industrialization. Alam et al. (2011) discussed seasonal variability of MODerate resolution Imaging Spectroradiometer (MODIS, Chu et al., 2003; Wang and Christopher, 2003) derived AOD for different areas of Pakistan during 2002-2008. They found the highest AOD values during summer season linked to high dust/sand aerosols. Sreekanth (2013) reported an increasing trend in MODIS-AOD during 2002-2011 over Bangalore (India) due to sustained increase in the seasonal averaged AOD during summer. Gupta et al. (2013) analyzed the spatial and temporal patterns of aerosols over two megacities of Pakistan namely Karachi and Lahore by using MODIS data for the period 2001-2010. The major aim of their study was to evaluate the standard of MODIS data for air quality and climate applications. Tariq et al. $(2015,2016)$ have analyzed the optical properties of aerosols over Lahore using multi-sensor data during intense biomass burning events.

To the best of our knowledge, no detailed study has been conducted so far to analyze the spatio-temporal distributions of aerosol parameters such as mass concentration (MC), small mode fraction (SMF) and Angstrom exponent (AE) over Pakistan. The main objective of this paper is to investigate the spatio-temporal distributions and trends in aerosol parameters over Pakistan using long-term (15 years) data. In the present study, Terra-MODIS data is used for the period April 2000-March 2014 to analyze the AOD $(550 \mathrm{~nm})$, Angstrom exponent (470-660) (AE $470-660)$, SMF and MC. AOD from different satellite sensors have also been compared with ground-based AOD. Furthermore, Terra-AOD has also been compared with other satellite-based observations obtained from Aqua, MISR and SeaWiFS.

\section{Material and methods}

\section{Study area}

Pakistan is a South Asian country with estimated population exceeding 191 million and an area of about $796100 \mathrm{~km}^{2}$. It is bordered by India to the east, China to the northeast, Afghanistan to the west and Iran to the southwest (Fig. 1a). It also has a coastline of about $1046 \mathrm{~km}$ along the Arabian Sea and Gulf of Oman. Ranging from the coastal areas of the south to the glaciated mountainous areas of the north, Pakistan's land-cover varies from plains to deserts (i.e. Cholistan and Thar), forests, hills and 
plateaus. These different landscapes together with extremely variable climatic conditions make Pakistan a distinctive country for studying spatio-temporal patterns of aerosols (Alam et al., 2011). Major sources of anthropogenic aerosols in Pakistan are petroleum refineries, power plants, fertilizer plants, industries, crop residue burning and fossil fuels combustion in vehicles (Ghauri et al., 1994; Biswas et al., 2008; Tariq and Ali, 2015). High amounts of aerosols are released from industrial areas and biomass burning in northeastern Pakistan and regions across the border in India such as Amritsar, Chandigarh and Bathinda (Raja et al., 2010). Figure $1 b$ shows fire aggregates retrieved by MODIS-Terra and MODIS-Aqua during April 2000-March 2014. The figure clearly exhibits high frequency of fire events in Indo-Gangetic plain (IGP). Transboundary aerosols also contribute to the aerosol burden over Pakistan (Tariq et al., 2015, 2016). Winds transport aerosols released from coal based power plants in India to northeastern Pakistan. Dust/sand aerosols are the major source of natural aerosols in Pakistan. High amounts of desert dust dominate the central and southern parts of Pakistan due to comparatively low humidity and high temperature (Tariq and Ali, 2015) (Fig. 2). Dust storms in the region are largely associated with the easterly movements of low-pressure systems (Tariq and Ali, 2015).

In order to show prevailing meteorological conditions, specific humidity at $850 \mathrm{mb}$, wind speeds at $850 \mathrm{mb}$ and surface temperature have been mapped during April 2000March 2014 using NCEP-Reanalysis-2 data from NOAA/OAR/ESRL PSD, Boulder, Colorado, USA (Fig. 2). It can be noted from Figure $2 a$ that central and southeastern parts of Pakistan have high temperatures (above $20{ }^{\circ} \mathrm{C}$ ). Figure $2 b$ shows that northeastern parts of Pakistan are characterized by relatively high values of average specific humidity (> $6 \mathrm{~g} / \mathrm{kg}$ ), whereas central and southeastern areas have relatively dry air (specific humidity $<6 \mathrm{~g} / \mathrm{kg}$ ). In Figure $2 c$ strong winds $\left(\sim 3 \mathrm{~ms}^{-1}\right)$ can be observed over southern parts of Pakistan.

a

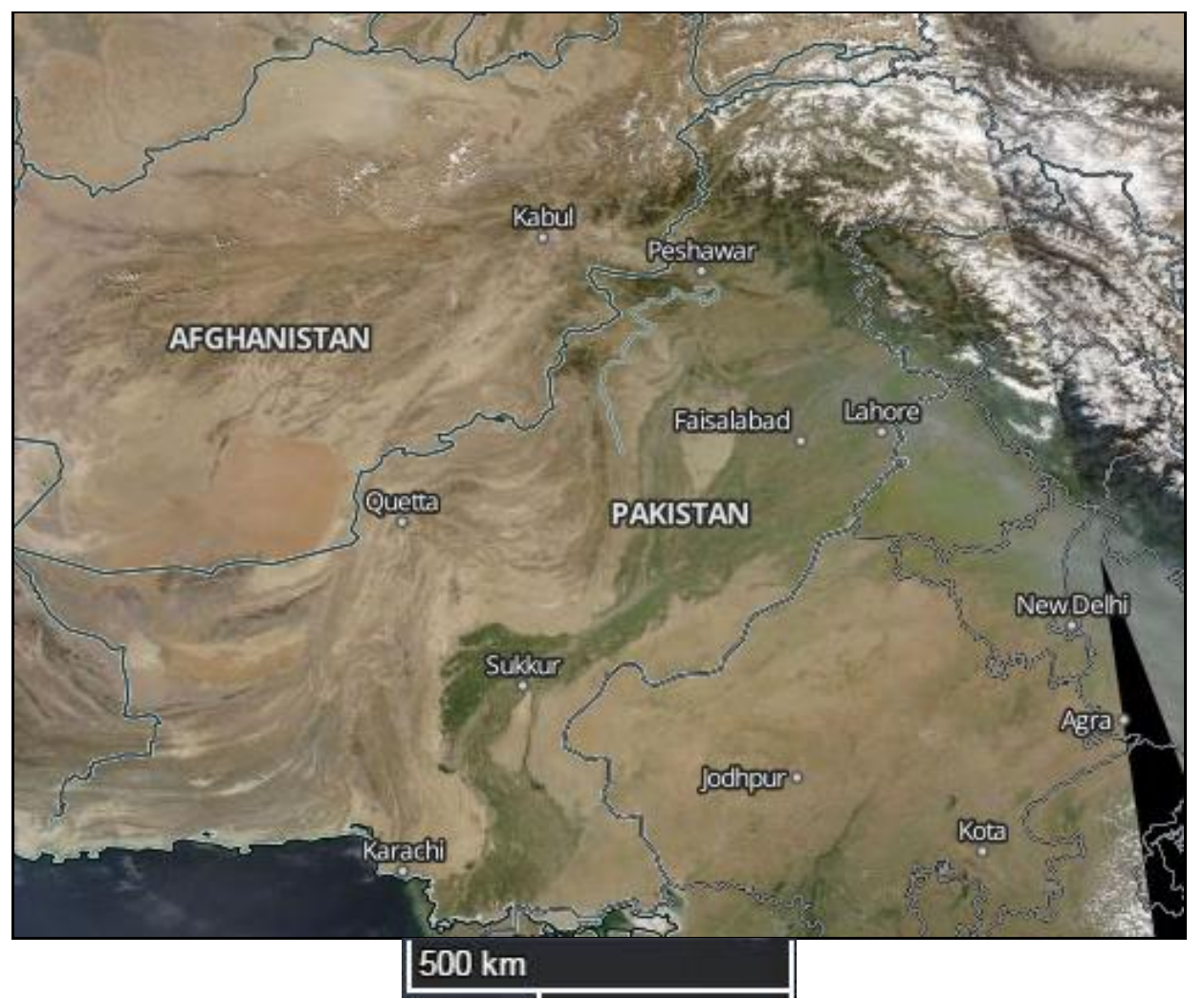


b

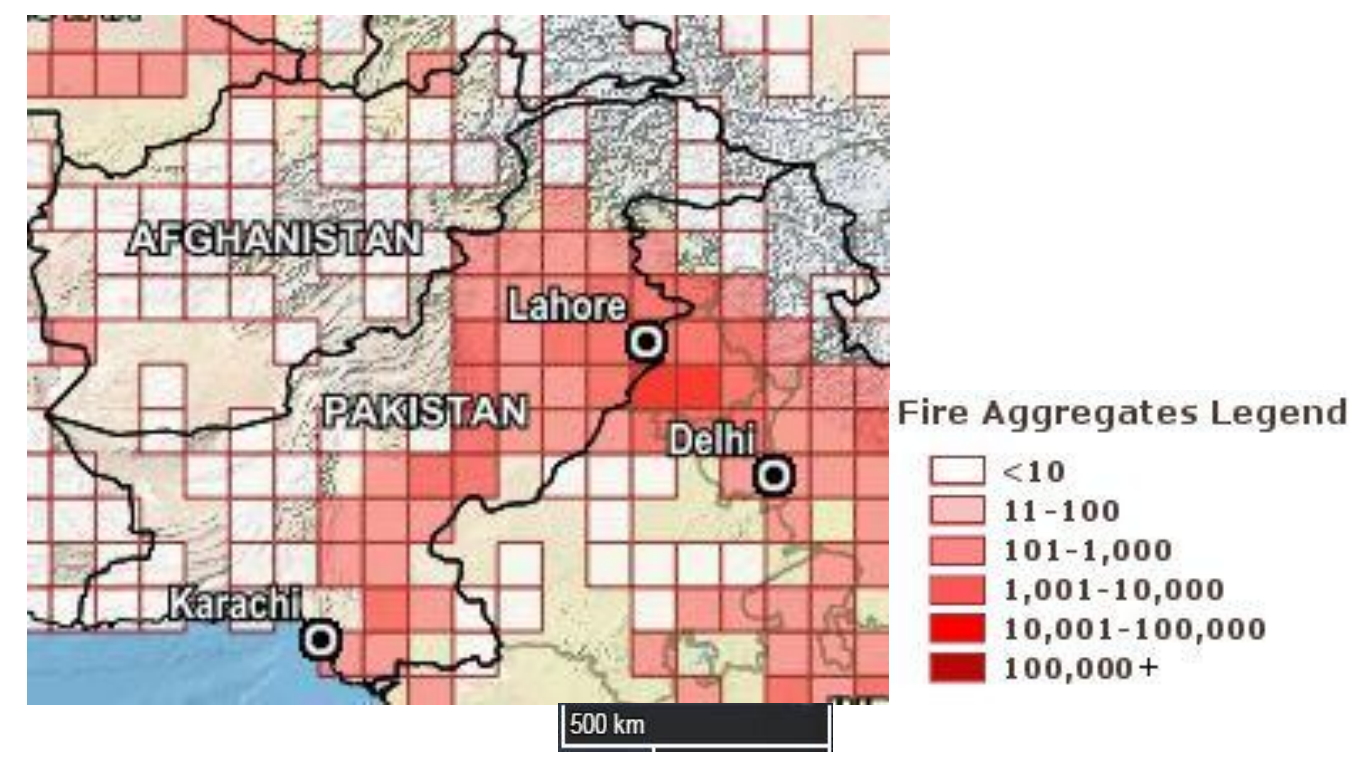

Figure 1. (a) True color MODIS-image of Pakistan showing major cities, and (b) fire aggregates retrieved from MODIS Terra and Aqua during April 2000-March 2014

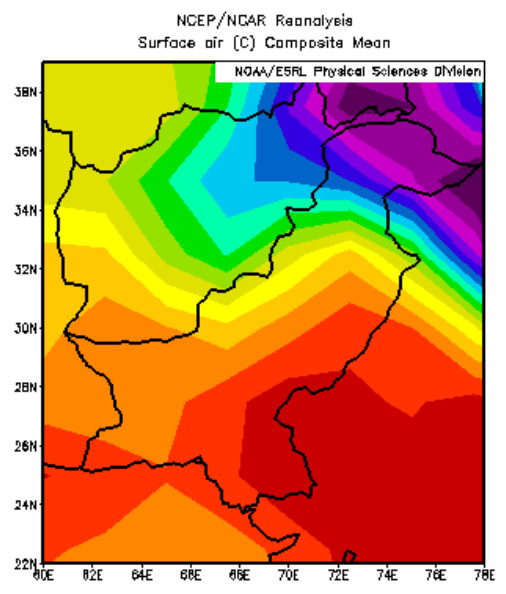

$\mathbf{a}$

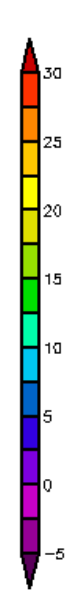

NCEP/NCAR Ragnalyeis

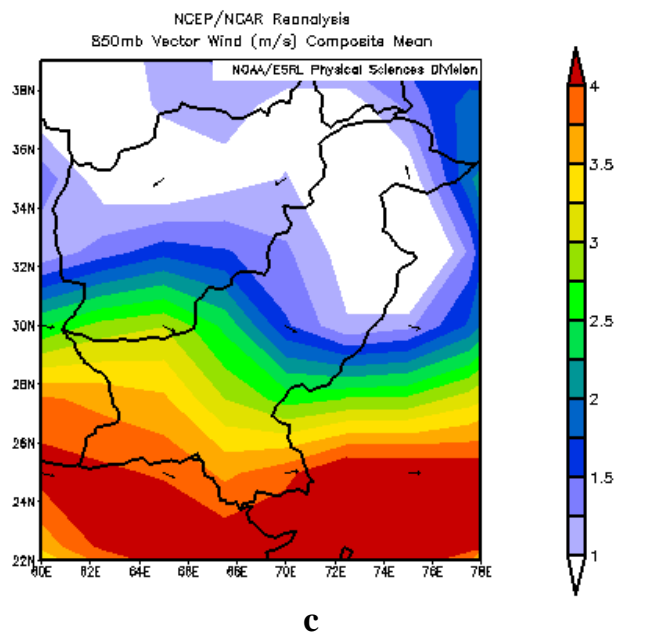

NCEP/NCAR Ragnalyeis

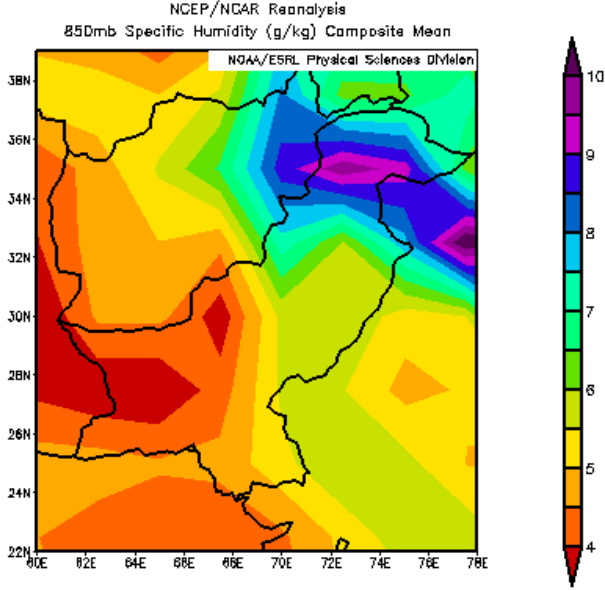

b

Figure 2. Maps of (a) surface temperature $\left({ }^{\circ} \mathrm{C}\right)$, (b) specific humidity $(\mathrm{g} / \mathrm{kg})$ at $850 \mathrm{mb}$, and (c) vector wind speeds at $850 \mathrm{mb}$ over Pakistan during April 2000 to March 2014 


\section{Methodology and datasets}

In the present study we have used Terra-MODIS data for the period April 2000March 2014 to analyze AOD $(550 \mathrm{~nm})$, Angstrom exponent $\left(\mathrm{AE}_{470-660}\right)$, small mode fraction (SMF) and mass concentration (MC) of aerosols over Pakistan. AOD from different satellite sensors have also been compared with ground-based AOD. Spatail maps of AOD, AE ${ }_{470-660}, \mathrm{SMF}$ and MC have been produced uding MATLAB software. The trends in seasonal-mean latitudinal and longitudinal averaged values of Terra-AOD are simulated with the help of linear equations. Linear trend parameters, correlation coefficients and relative changes (\%) per year for AOD, AE, SMF and MC on seasonal and annual basis are also calculated.

\section{MODIS}

MODIS sensor was launched by NASA onboard Terra satellite in 1999 and Aqua satellite in 2002. MODIS is primarily designed to monitor aerosol fields, cloud cover and radiation budget (King et al., 1992). Terra satellite crosses the equator from north to south in the morning (10:30 local time) while Aqua satellite crosses it from south to north in the afternoon (13:30 local time). The orbits of Terra and Aqua are so designed that they image the whole globe in one to two days. MODIS instrument has a swath width of $\sim 2330 \mathrm{~km}$ and acquires data in thirty-six spectral bands. It provides a high radiometric resolution (12 bits) data in all the thirty-six spectral bands from $0.4 \mu \mathrm{m}$ to $14.4 \mu \mathrm{m}$, with spatial resolution of $1 \mathrm{~km}, 0.5 \mathrm{~km}$ and $0.25 \mathrm{~km}$ depending on the wavelength band. In the present work Terra-MODIS derived AOD (550 nm), AE $470-660$, SMF and MC have been analyzed for a period from 2000 to 2014. We have used monthly gridded MOD08_M3.051 data product with spatial resolution of $1^{\circ} \times 1^{\circ}$ obtained from NASA Goddard Earth Sciences Data and Information Center. These datasets are available via Giovanni website: http://giovanni.gsfc.nasa.gov. Missing values are not considered while calculating annual/monthly means and standard deviations. Due to difference in the surface characteristics, aerosol retrieval algorithms of MODIS are different for oceans (Tanré et al., 1997) and land (Kaufman et al., 1997). The aerosol retrieval algorithms have recently been greatly improved to correct the systematic biases (Remer et al., 2005; Levy et al., 2007). Detailed description of MODIS sensor, data products, retrieval algorithms, retrieval accuracy and validation can be found elsewhere (e.g., Remer et al., 2005 and references therein).

\section{AERONET}

The AErosol RObotic NETwork (AERONET) is a network of ground based remote sensing instruments administered by NASA (Holben et al., 1998). It provides detailed data of optical and physical properties of aerosols. AERONET data are processed at three different quality levels: level 1 (unscreened), level 1.5 (cloud screened) and level 2 (quality assured). AERONET instrument measures the direct sun and sky radiances within spectral ranges of $340 \mathrm{~nm}-1020 \mathrm{~nm}$ and $440 \mathrm{~nm}-1020 \mathrm{~nm}$ respectively (Holben et al., 1998). AOD and AE are calculated from direct sun radiances while single scattering albedo, asymmetry parameter and refractive index are computed from sky radiances (Dubovik and King, 2000). Currently, there are only two operational AERONET sites in Pakistan: Lahore (a central location in Pakistan) and Karachi (a coastal city of Pakistan). Lahore has a semi arid climate with hot and long summers and cool winters (Ali et al., 2014). From May to September temperatures are high with dust 
storms followed by rainfall. Karachi is the most densely populated city of Pakistan and located in southern region adjacent to Arabian Sea. Being a coastal city, Karachi has relatively mild climate. It has one of the busiest ports of the region and is a hub of industrial and economic activity in Pakistan. In this study Terra-AOD observations have been compared with level-2 AERONET-AOD values over Lahore and Karachi.

\section{MISR}

The MISR (Multi-angle Imaging Spectroradiometer) onboard Terra satellite was launched by NASA in 1999 at an altitude of $705 \mathrm{~km}$. It has variable spatial resolutions of $1 \mathrm{~km}, 275 \mathrm{~m}$ and $250 \mathrm{~m}$ and temporal resolution of 16 days. It can view the Earth at nine different angles and hence it has the capability to measure the amount of sunlight scattered in different directions (Diner et al., 2001). It is primarily designed to monitor trends and types of aerosol particles produced from natural and anthropogenic activities. In this study we have used MISR AOD at $555 \mathrm{~nm}$ and prepared at level 3 version 004 available from NASA Goddard Earth Sciences Data and Information Center. Detailed information of MISR instrumentation, retrieval algorithms and methodology can be found in Diner et al. (2001) and Kahn et al. (2005, 2010).

\section{SeaWiFS}

The SeaWiFS instrument onboard SeaStar satellite was launched in 1997. It has a swath width of $1502 \mathrm{~km}$ and provides global coverage in approximately 2 days. It was primarily designed to measure ocean color parameters and has a very accurate and stable calibration to measure small contribution of the ocean to the reflected solar radiance at top-of-atmosphere (TOA) (Eplee Jr. et al., 2011). The high quality of calibration and long-term data of SeaWiFS make its AOD more reliable. Its deep blue aerosol retrieval algorithm over land was developed by Hsu et al. (2004, 2006). SeaWiFS SWDB_L3M10_HDF4.004 AOD product at $550 \mathrm{~nm}$ is used which can be downloaded from NASA Goddard Earth Sciences Data and Information Center.

\section{Results and discussion}

\section{Comparison of satellite sensed AOD with ground based AOD}

Ground-based observations are used to validate satellite aerosol products. Daily Terra-AOD, Aqua-AOD, MISR-AOD and SeaWiFs-AOD have been compared with ground based interpolated AERONET-AOD for Lahore and Karachi during 2006-2013 (Fig. 3). For the validation of AOD derived from Terra, Aqua, MISR and SeaWiFs, AERONET observations taken at 15-min intervals under cloud free conditions are used (Holben et al., 1998). For the purpose of comparison, only those data pixels have been considered that fall within a radius of about $27.5 \mathrm{~km}$ from the selected AERONET site (Petrenko et al., 2012). In order to have observations closest in time, only those observations are taken that fall within $\pm 30 \mathrm{~min}$ (30 min before and after) of satellite overpass time (Petrenko et al., 2012).

It can be seen in Figure $3 a-h$ that the values of coefficient of determination $\left(R^{2}\right)$ for Lahore are found to be slightly lower than Karachi which is in partial agreement with Bibi et al. (2015). Slope and intercept of linear regression calculated from the comparison of collocated datasets are of great importance (Levy et al., 2010). The slope of linear regression equation demonstrates the closeness of the assumed aerosol type to 
the local aerosol type over a particular region, and the intercept reveals error due to surface reflectance (Tripathi et al., 2005; Hyer et al., 2011). The slope $=1$ and intercept $=0$ indicate a perfect correlation between satellite observations and groundbased AOD (Tripathi et al., 2005). Slope $>1$ indicates over estimation while slope $<1$ refers to under estimation. Non-zero intercepts are linked with the errors in calibration or in surface reflectance (Chu et al., 2002; Tripathi et al., 2005).

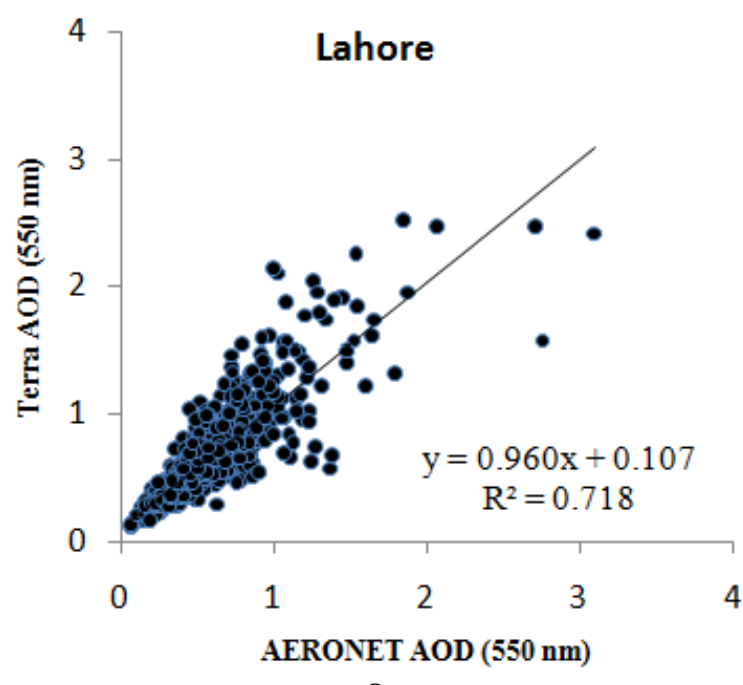

a

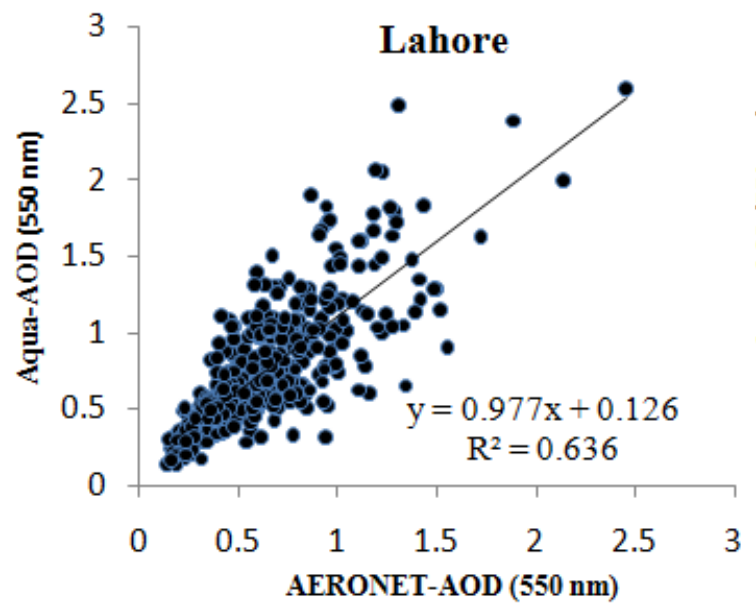

c

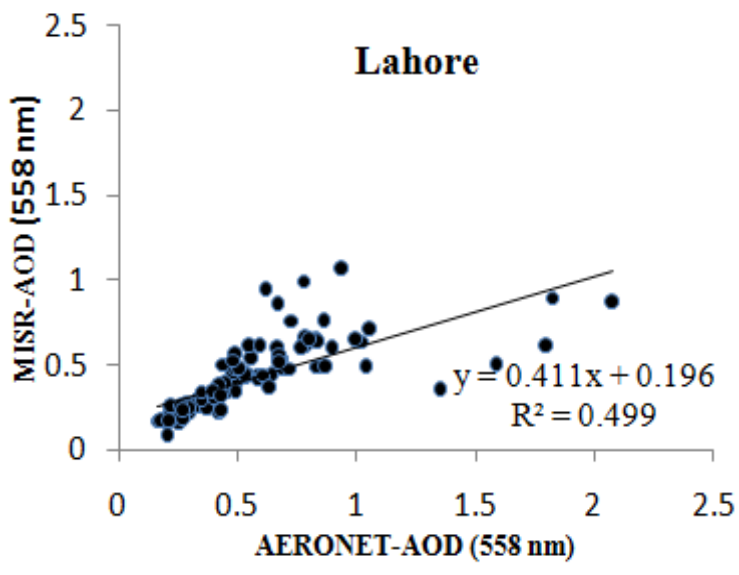

e

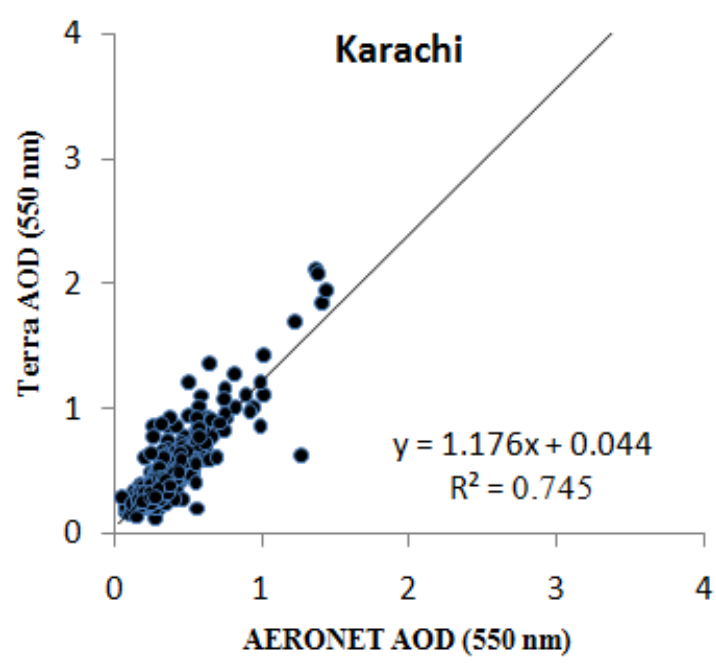

b
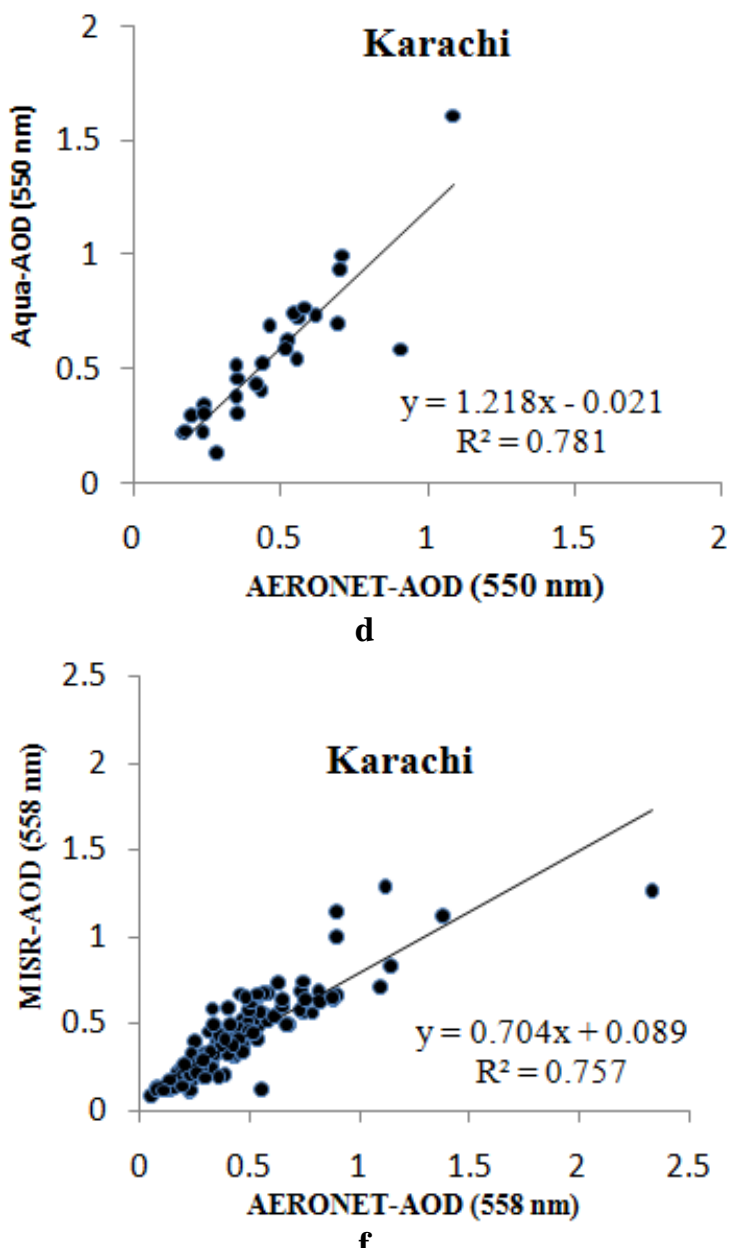

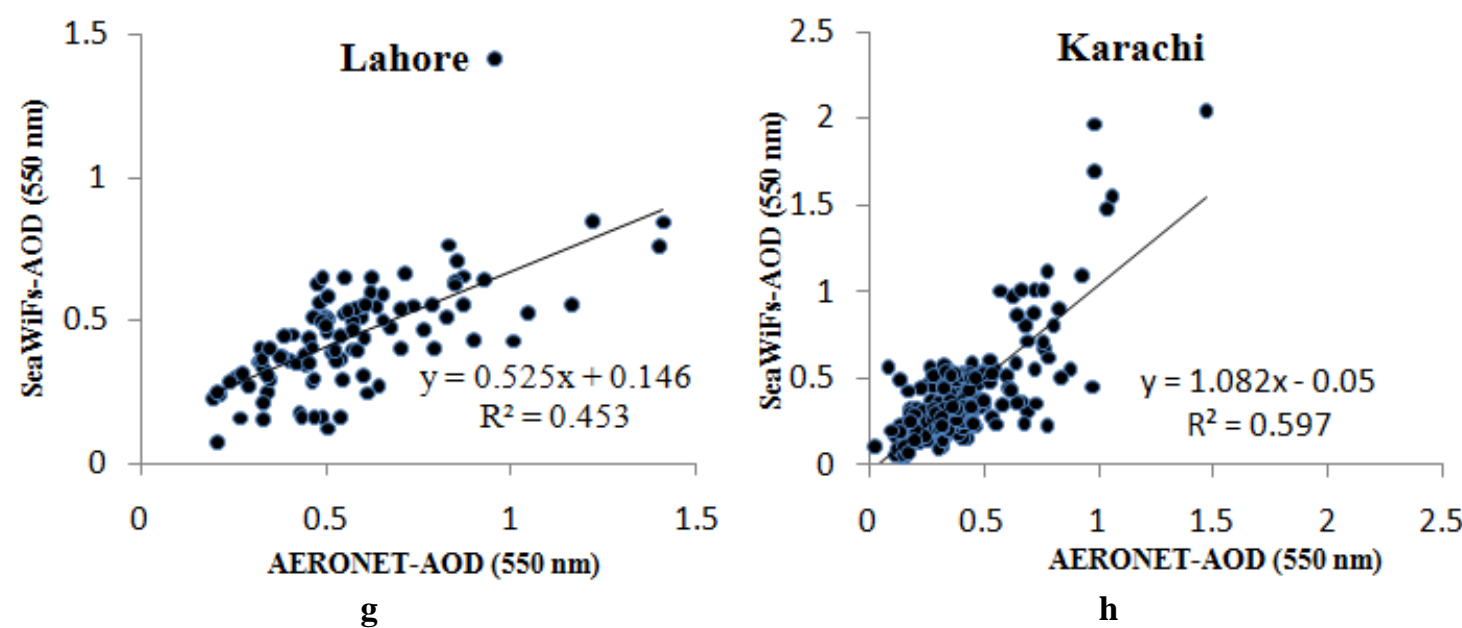

Figure 3. Validation of daily $(a, b)$ Terra-AOD, $(c, d)$ Aqua-AOD, $(e, f) \operatorname{MISR}-A O D$ and $(g, h)$ SeaWiFs-AOD with ground based interpolated AERONET-AOD over Lahore and Karachi for the period 2006-2013. The coefficient of determination $\left(R^{2}\right)$ and equation of linear fit are also given

All the satellite sensors exhibited under estimation over Lahore while for Karachi all the satellite sensors except MISR showed over estimation. In the present study, values of intercepts for Lahore are found to be $0.107,0.126,0.196$ and 0.146 for Terra, Aqua, MISR and SeaWiFs respectively. For Karachi, values of intercepts are found to be 0.044, $-0.021,0.089$ and -0.05 for Terra, Aqua, MISR and SeaWiFs respectively.

\section{Comparison of Terra-AOD with Aqua, MISR and SeaWiFS observations}

To achieve accuracy in measurements and realize the remote sensing capabilities, numerous studies have compared MODIS observations with MISR data (Prasad and Singh, 2007; Xiao et al., 2009; Kumar et al., 2015). Comparison of monthly Terra-AOD with available observations of Aqua-AOD (550 nm), MISR-AOD (555 nm), and SeaWiFS-AOD $(550 \mathrm{~nm})$ during the study period has been shown in Figure 4 . The highest correlation $\left(R^{2}=0.968\right)$ observed between Terra-AOD and Aqua-AOD is due to the fact that both Terra and Aqua have the same type of sensor and algorithms for aerosol retrieval (Remer et al., 2005). Also slope of 1.044 and y-intercept of -0.011 indicate very slight difference in the observed AOD from these platforms. This small inconsistency is associated with different overpass times of Terra (10:30 local time) and Aqua (13:30 local time). The coefficient of determination $\left(R^{2}\right)$ between Terra-AOD and MISR-AOD is found to be 0.919. Slope (0.680) and y-intercept (0.018) of linear fit between Terra-AOD and MISR-AOD show that the MISR under-estimates the values of AOD as compared to Terra. These differences are attributed to different algorithms and wavelengths used for the retrieval of aerosols (Martonchik et al., 1998; Diner et al., 1998; Remer et al., 2005). The lowest coefficient of determination $\left(R^{2}=0.750\right)$ is found between Terra-AOD and SeaWiFS-AOD. Values of slope (0.359) and y-intercept (0.117) of linear fit for SeaWiFS-AOD also exhibit under estimation. Despite of having same wavelength of operation, the different aerosol model assumptions and instrument calibrations of Terra-MODIS and SeaWiFS cause this under estimation (Hsu et al., 2004, 2006; Remer et al., 2005). 

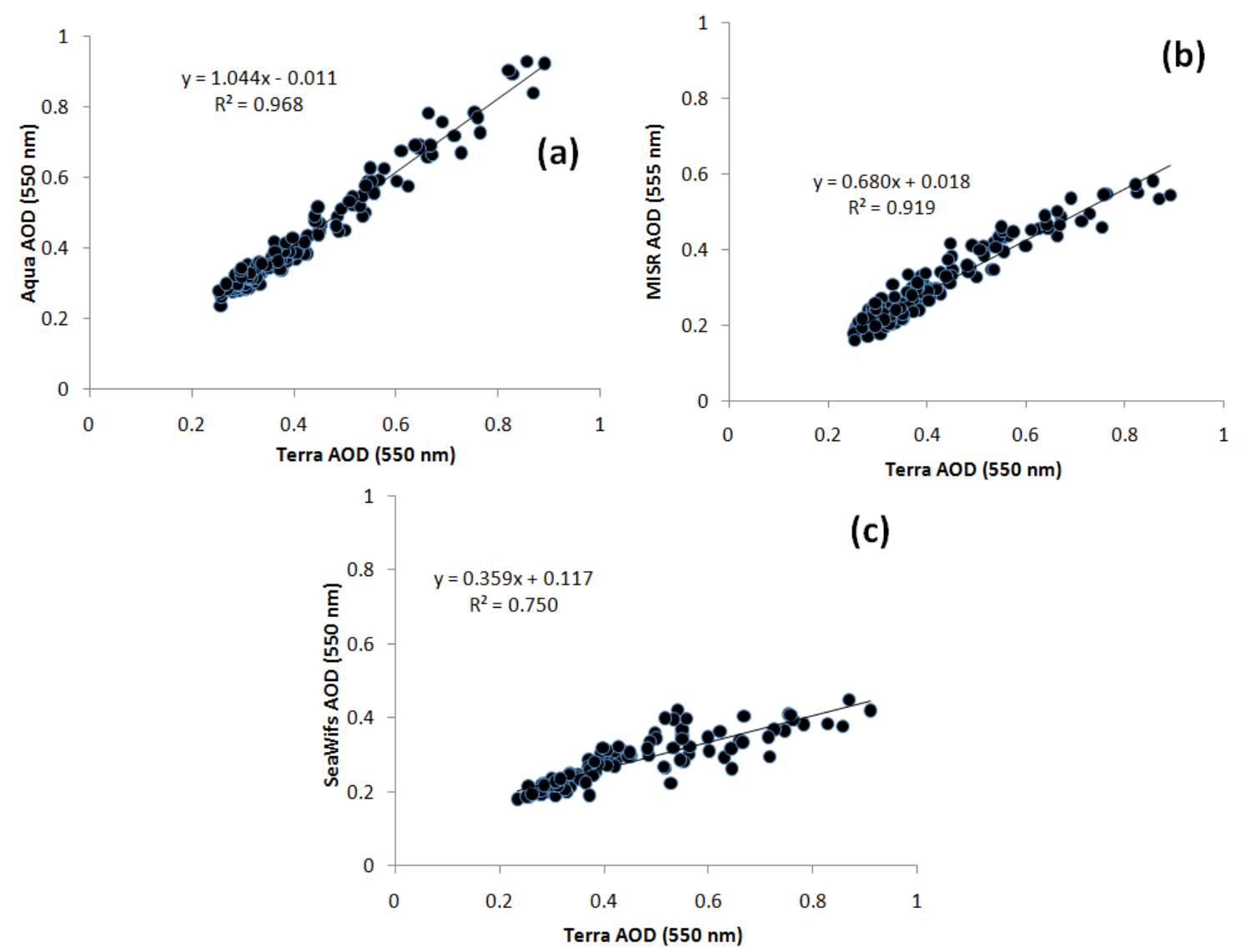

Figure 4. Comparison between (a) Terra-AOD (550 nm) and Aqua-AOD (550 nm), (b) Terra$A O D(550 \mathrm{~nm})$ and MISR-AOD (555 $\mathrm{nm})$ and (c) Terra-AOD (550 nm) and SeaWiFS-AOD (550 $n m)$ over Pakistan during the study period. The equation of linear fit and coefficient of determination $\left(R^{2}\right)$ are also given

\section{Spatial distributions of aerosol parameters}

Spatial distributions of Terra-AOD, $\mathrm{AE}_{470-660}$, SMF and MC for the period 20002014 have been shown in Figure 5. White spaces in the figure represent no data/fill values. A significant spatial variability in Terra-AOD values $(0.15-0.87)$ has been observed as shown in Figure 5a. It can also be noted from Figure $5 a$ that high values $(\sim 0.8)$ of mean annual Terra-AOD exist over northeastern and southern Pakistan. Several studies have reported heavy air pollution due to intense crop residue burning in Pakistan and adjoining regions (Ul-Haq et al., 2015a, b, 2016, 2017). Tariq and Ali (2015) highlighted high aerosol burden over northeastern Pakistan due to open field crop residue burning. Also elevated concentrations of aerosols are associated with the activities at industrial areas in northeastern Pakistan and regions across the border in India such as Amritsar, Chandigarh and Bathinda (Raja et al., 2010). Wind patterns favor transport of aerosols released from anthropogenic activities such as biomass burning and fossil fuel combustion in power plants in India to northeastern Pakistan. On the other hand, high AOD values over the southern Pakistan are mainly contributed by desert/dust aerosols largely transported from local areas including Thar and Cholistan deserts (Tariq and Ali, 2015). Influx of desert/dust aerosols from desert regions of Arabia and Africa (Middleton, 1986; Prospero et al., 2002; Singh et al., 2004; Prasad 
and Singh, 2007; Kumar et al., 2012; Alam et al., 2014; ul-Haq et al., 2016) also contributes to the aerosol burden over this region.

Furthermore, the spatial distribution of Terra-AOD follows the Sulaiman-Kirthar range pattern that acts as a barrier for the desert/dust aerosols coming from the Thar and Cholistan deserts (Tariq and Ali, 2015). Alam et al. (2011) also found high AOD values over southern Pakistan due to high population, increased urbanization, heavy industrialization, and nearness of Thar and Cholistan deserts (Qureshi, 2010). We observe low values of Terra-AOD over northern and northwestern parts of Pakistan due to the fact that most of the areas in northern and northwestern Pakistan are agricultural and less populated in agreement with Alam et al. (2011).

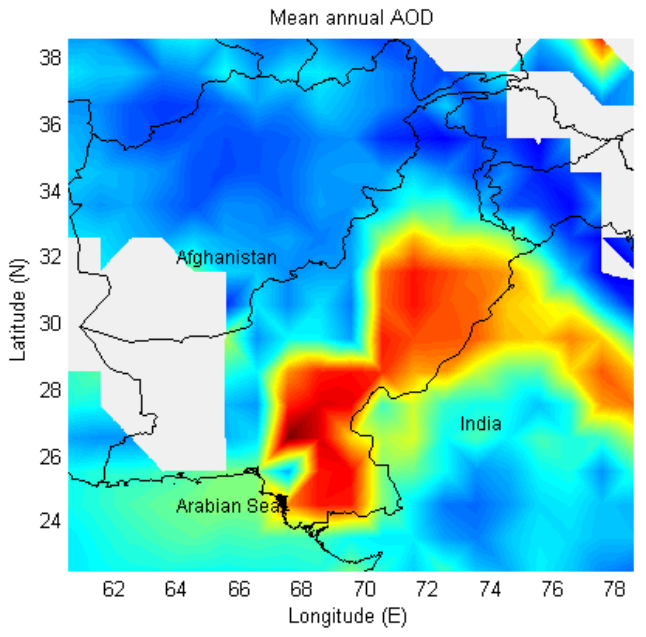

a

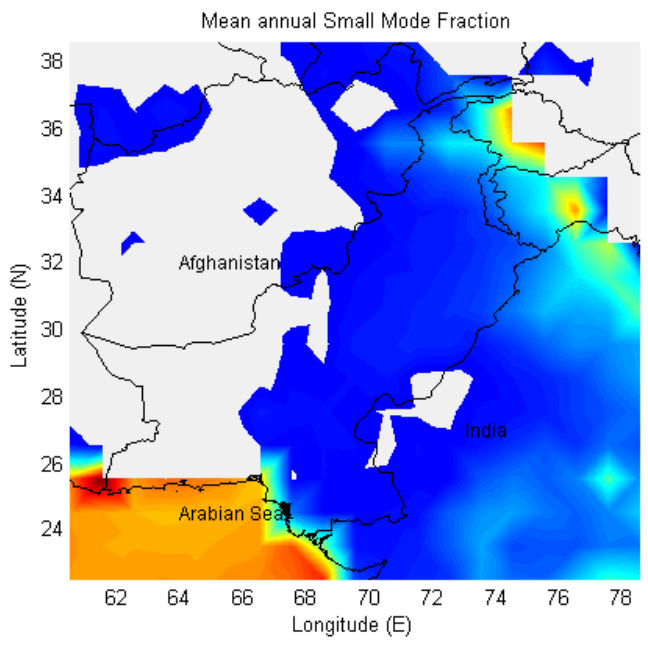

c

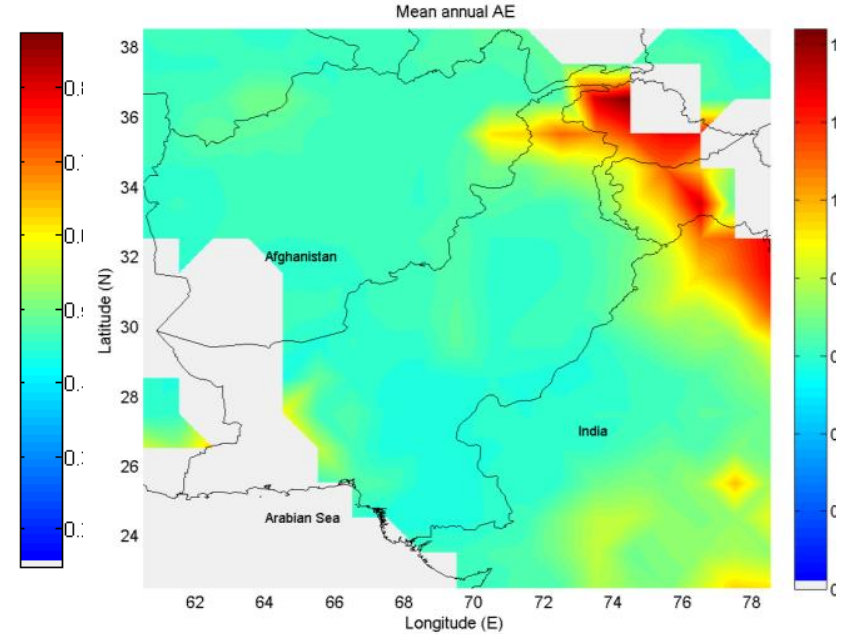

b

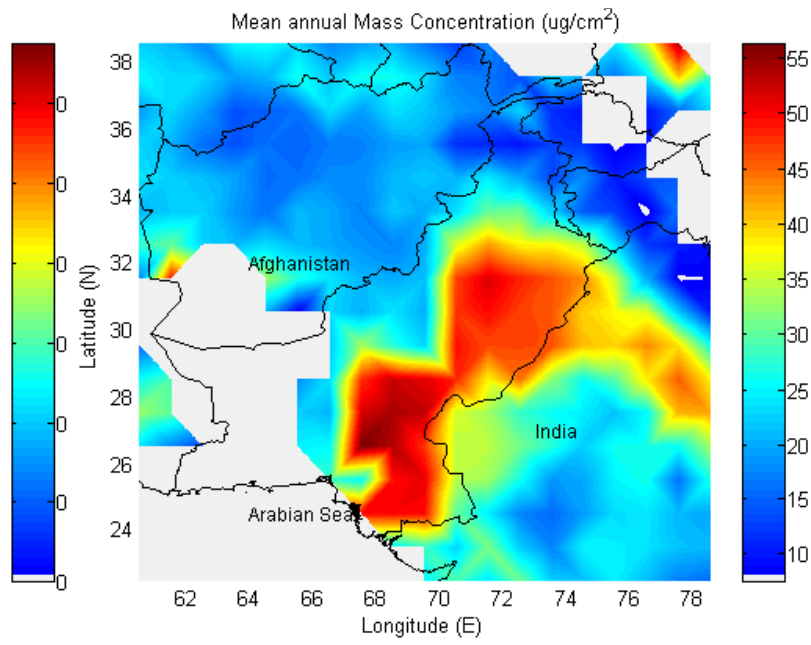

d

Figure 5. Mean annual spatial distributions of (a) Terra-AOD, (b) AE $470-660$, (c) SMF and (d) MC of aerosols over Pakistan from April 2000 to March 2014

Since AOD only describes the overall aerosol burden without any information of aerosol composition, we have also analyzed other parameters such as Angstrom exponent and small mode fraction to differentiate the fine mode and coarse mode aerosol particles. The Angstrom exponent (AE) is an important qualitative parameter to 
assess the size of aerosol particles (Angstrom, 1929). It is inversely related to the size of aerosol particles; values of $\mathrm{AE}$ less than or equal to 1 indicate the dominance of coarse mode aerosol particles (radii $\geq 0.5 \mu \mathrm{m}$ ) such as dust and sea-salt, while $\mathrm{AE} \geq 1$ indicates the dominance of fine mode aerosol particles (radii $\leq 0.5 \mu \mathrm{m}$ ) such as urban pollution and biomass burning (Westphal and Toon, 1991; Eck et al., 1999). The AE has been used in various studies to assess the size distribution and classify different types of aerosols (Eck et al., 1999, 2001; O’Neill et al., 2001; Schuster et al., 2006; Kalapureddy and Devara, 2008; Kedia and Ramachandran, 2009). Figure 5b shows spatial distribution of mean annual $\mathrm{AE}_{470-660}$ over Pakistan during the study period. Wide range of $\mathrm{AE}_{470-660}$ (0.56 to 1.44) indicates considerable variability in the size of aerosol particles. The northern Pakistan is characterized by high values (greater than 0.8) of $\mathrm{AE}_{470-660}$ due to dominance of fine mode aerosols (i.e., anthropogenic aerosols), whereas relatively low values (less than 0.8) over southern Pakistan indicate the dominance of coarse mode aerosols (i.e., sand/dust). Various epidemiological studies have reported a significant correlation between exposure to fine particles in the atmosphere and adverse health effects. Therefore, people residing in the northern parts of Pakistan may experience more harmful health effects due to fine mode aerosol particles.

SMF is the ratio of small mode AOD to the total AOD (Kaufman et al., 2005a, b). High values of SMF are associated with small aerosol particles such as those released from anthropogenic sources (i.e. biomass burning) while low values of SMF indicate naturally occurring large aerosol particles such as sea-salt and dust (Bellouin et al., 2005). The spatial distribution of mean annual SMF (Fig. 5c) is found to be almost similar to that of $\mathrm{AE}_{470-660}$ i.e., high values over northern Pakistan and low values over southern Pakistan. It can further be noted from Figure $5 c$ that fine mode aerosols are dominating over Arabian Sea. The high values of SMF over Arabian Sea are possibly associated with the presence of sea-salt aerosols. Figure $5 d$ shows the spatial distribution of mean annual MC of aerosols over Pakistan. It can be noted that the spatial distribution of $\mathrm{MC}$ is quite similar to that of AOD. The MC showed a significant spatial variability (i.e., 7.6 to $56.2 \mu \mathrm{g} / \mathrm{cm}^{2}$ ). The high values of MC over south and northeastern Pakistan indicate heavy aerosol loading.

\section{Latitudinal and longitudinal gradients in seasonal AOD}

Figure 6 shows latitudinal and longitudinal gradients in seasonal Terra-AOD during 2000-2014 over the study region. The latitudinal AODs are averaged over a longitude range of $60.5^{\circ} \mathrm{E}-78.5^{\circ} \mathrm{E}$, and longitudinal AODs have been averaged over a latitude range of $22.5^{\circ} \mathrm{N}-38.5^{\circ} \mathrm{N}$. Figure $6 a$ shows that Terra-AOD remained relatively high on all the latitudes during summer and low during the winter. Unstable atmosphere in summers uplifts the aerosols causing enhanced values of AOD. On the contrary, stable atmosphere during winters entraps the aerosols to lower heights resulting in small values of AOD in agreement with Prasad et al. (2007), Alam et al. (2010) and Ali et al. (2014). Prasad et al. (2007) analyzed the aerosol variations over IGP and they found higher AOD in summer and lower AOD in winter. Alam et al. (2010) found higher values of AOD in summer and lower values in winter over ten different cities of Pakistan. Similarly, Ali et al. (2014) reported high value of AERONET derived AOD over Lahore, a northeastern megacity of Pakistan, due to increased temperatures and frequent dust storms. As a general rule the Terra-AOD in all the four seasons has increased northward from $22.5^{\circ} \mathrm{N}$ with a maximum value at $28.5^{\circ} \mathrm{N}$ and then it 
decreases towards $35.5^{\circ} \mathrm{N}$ followed by a little increase between $35.5^{\circ} \mathrm{N}-38.5^{\circ} \mathrm{N}$. The maximum decrease (0.63) in latitudinal Terra-AOD is observed during summer season. It showed averaged peak values of $0.52,0.92,0.57$ and 0.47 during spring, summer, autumn and winter seasons, respectively, at a latitude of $28.5^{\circ} \mathrm{N}$. The peak values at $28.5^{\circ} \mathrm{N}$ is linked to biomass burning in IGP covering northeastern Pakistan and regions across the border in India (Fig. 1b; Tariq et al., 2016; ul-Haq et al., 2016). The lowest AODs are observed to be $0.29,0.30,0.20$ and 0.19 during spring, summer, autumn and winter seasons, respectively, at a latitude of $36^{\circ} \mathrm{N}$.

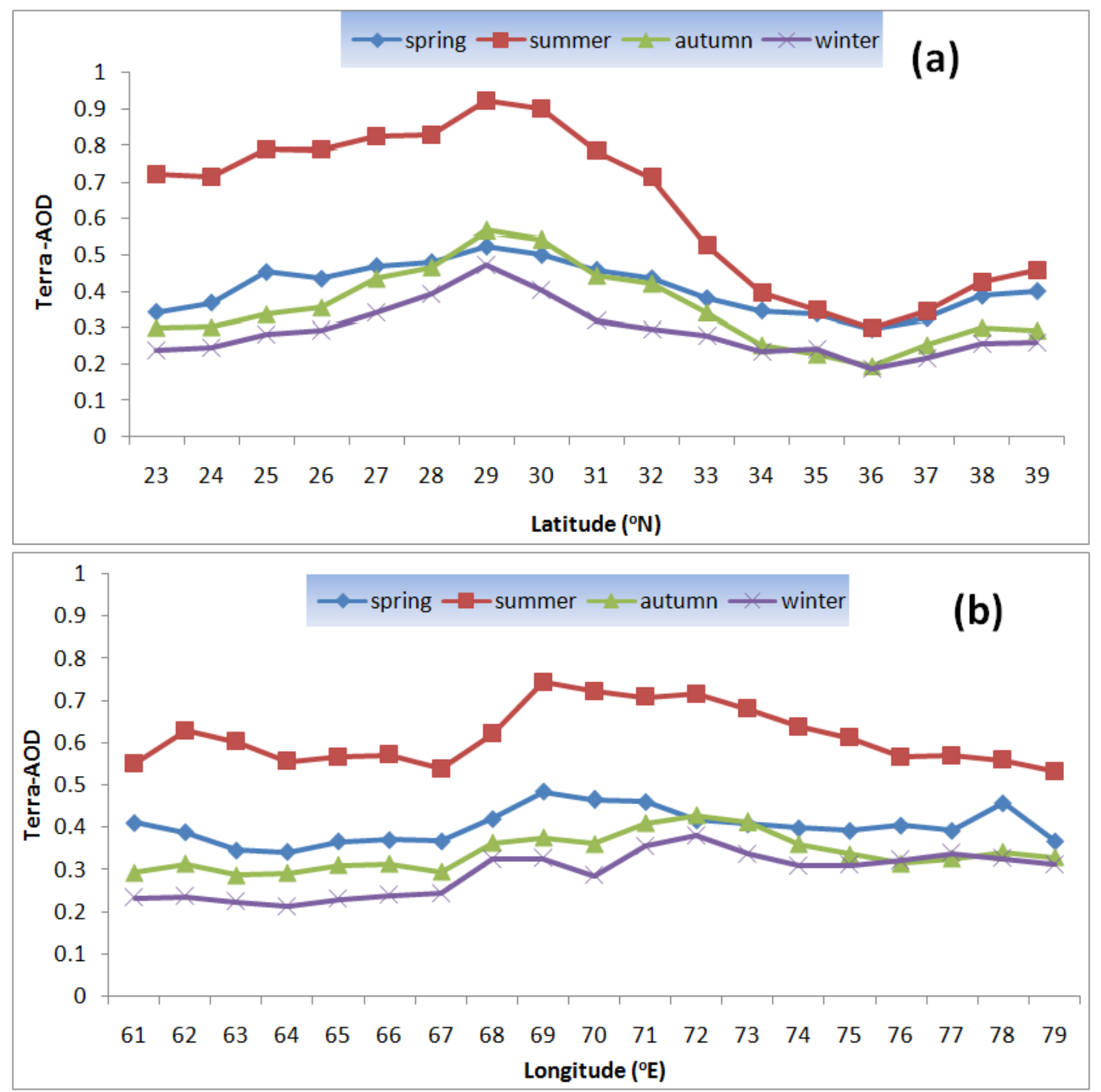

Figure 6. Seasonal variation in Terra-AOD over different latitudes (a) and longitudes $(b)$ in Pakistan during April 2000-March 2014

Figure $6 b$ shows seasonal variations in Terra-AOD over different longitudes in the study region. It is observed from the Figure $6 b$ that longitudinal Terra-AOD remains higher in summer than all the other seasons. During summer and spring, peak values of longitudinal Terra-AOD have been observed over $69^{\circ} \mathrm{E}$, while for winter and autumn 
peak values of Terra-AOD are observed over $72^{\circ} \mathrm{E}$. The peak values of longitudinal Terra-AOD are found to be $0.48,0.74,0.43$ and 0.38 during spring, summer, autumn and winter respectively. The peak values at $69^{\circ} \mathrm{E}$ and $72^{\circ} \mathrm{E}$ are associated with biomass burning and dust activity in part of IGP in Pakistan (see Figs. $1 b$ and $5 a$ ) (Tariq et al., 2016; ul-Haq et al., 2016). It is noticed that the trends in seasonal-mean latitudinal and longitudinal averaged values of Terra-AOD are better simulated with the help of following linear equations (Eqs. 1 and 2):

$$
\begin{array}{r}
\mathrm{AOD}=a \times \text { Lat }+b \\
\mathrm{AOD}=a \times \text { Long }+b
\end{array}
$$

Table 1 shows the values of constants $a$ and $b$, and coefficient of determination $\left(R^{2}\right)$ for different seasons over Pakistan during April 2000-March 2014. Some important conclusions drawn from the Table 1 are as follows:

(i) For latitudinal AOD, the slope $a$ is negative during all the seasons showing a decrease in Terra-AOD values towards northern Pakistan. Relatively large values of slope and $R^{2}$ in summer indicate less scatter in the linear fit with the largest south to north gradient for latitudinal AOD.

(ii) For longitudinal AOD, positive values of slopes during all the seasons indicate an increasing trend towards eastern Pakistan. Comparatively greater values of slopes and $R^{2}$ in winter season indicate less scatter in the linear fit with greatest west to east gradient for longitudinal Terra-AOD.

Table 1. Values of the $a$ and $b$ coefficients in the equation $A O D=a \times$ Lat $+b$ for latitudinal Terra-AOD and $A O D=a \times$ Long $+b$ for longitudinal Terra-AOD averaged over the longitudinal region $60.5^{\circ} \mathrm{E}-78.5^{\circ} \mathrm{E}$ and latitudinal region $22.5^{\circ} \mathrm{N}-38.5^{\circ} \mathrm{N}$, respectively, applied to the seasonal-mean values over Pakistan during the study period. The coefficient of determination $R^{2}$ represents the scatter of the data values from the fitting linear form

\begin{tabular}{c|c|c|c}
\hline Season & $\boldsymbol{a}$ & $\boldsymbol{b}$ & $\boldsymbol{R}^{\mathbf{2}}$ \\
\hline \multirow{3}{*}{ spring } & -0.0052 & For latitudinal AOD & 0.1564 \\
summer & -0.033 & 0.4545 & 0.5977 \\
autumn & -0.0085 & 0.9325 & 0.1548 \\
winter & -0.0049 & 0.4321 & 0.1141 \\
\hline \multicolumn{3}{|c}{ For longitudinal AOD } \\
spring & 0.0021 & 0.3358 & 0.085 \\
summer & 0.0003 & 0.6111 & 0.0007 \\
autumn & 0.0032 & 0.3082 & 0.174 \\
winter & 0.007 & 0.222 & 0.5844 \\
\hline
\end{tabular}

\section{Monthly climatological variations in aerosol parameters}

Figure $7 a$ shows a time series of monthly mean Terra-AOD spatially averaged over Pakistan along with standard deviations from April 2000 to March 2014. The TerraAOD ranges from 0.24 to 0.91 with an overall mean value of $0.43 \pm 0.16$. The highest value $(0.91)$ of Terra-AOD is observed in July 2001 while the lowest value (0.24) is found in December 2000. The broad range variations in time series of Terra-AOD 
values are attributed mainly to the high values observed over northeastern and southern Pakistan during summer season. The major contributors of high AOD values are dust aerosols originated from the local deserts (i.e., Thar and Cholistan) and anthropogenic activities. Desert/dust aerosols from desert regions of Arabia and Africa (Middleton, 1986; Prospero et al., 2002; Singh et al., 2004; Prasad and Singh, 2007; Kumar et al., 2012; Alam et al., 2014; ul-Haq et al., 2016) also contribute to the aerosol burden over the region. An overall negative change $(-15.4 \%)$ in the Terra-AOD values is observed indicating that the total aerosol burden is decreasing over Pakistan. However, a positive change $(10.6 \%)$ has been noticed in $\mathrm{AE}_{470-660}$ values (Fig. $7 b$ ) indicating that the contribution of fine mode aerosol particles towards total aerosol burden is increasing. The increasing trend in $\mathrm{AE}$ with time is linked to anthropogenic activates such as industrial production, residential combustion and biomass burning.

Gupta et al. (2013), while analyzing AOD observations from MODIS during 20012010, also showed a decreasing trend in AOD with slope of -0.07 over Lahore (Pakistan). Analysis shows that $\mathrm{AE}_{470-660}$ ranges from 0.60 to 0.86 with a mean of $0.68 \pm 0.06$. The highest value (0.86) of $\mathrm{AE}_{470-660}$ has been detected in December 2010 and the lowest value (0.60) in June 2001. Similarly, a positive change in SMF is also found (Fig. 7c) with an overall mean of $0.11 \pm 0.05$.

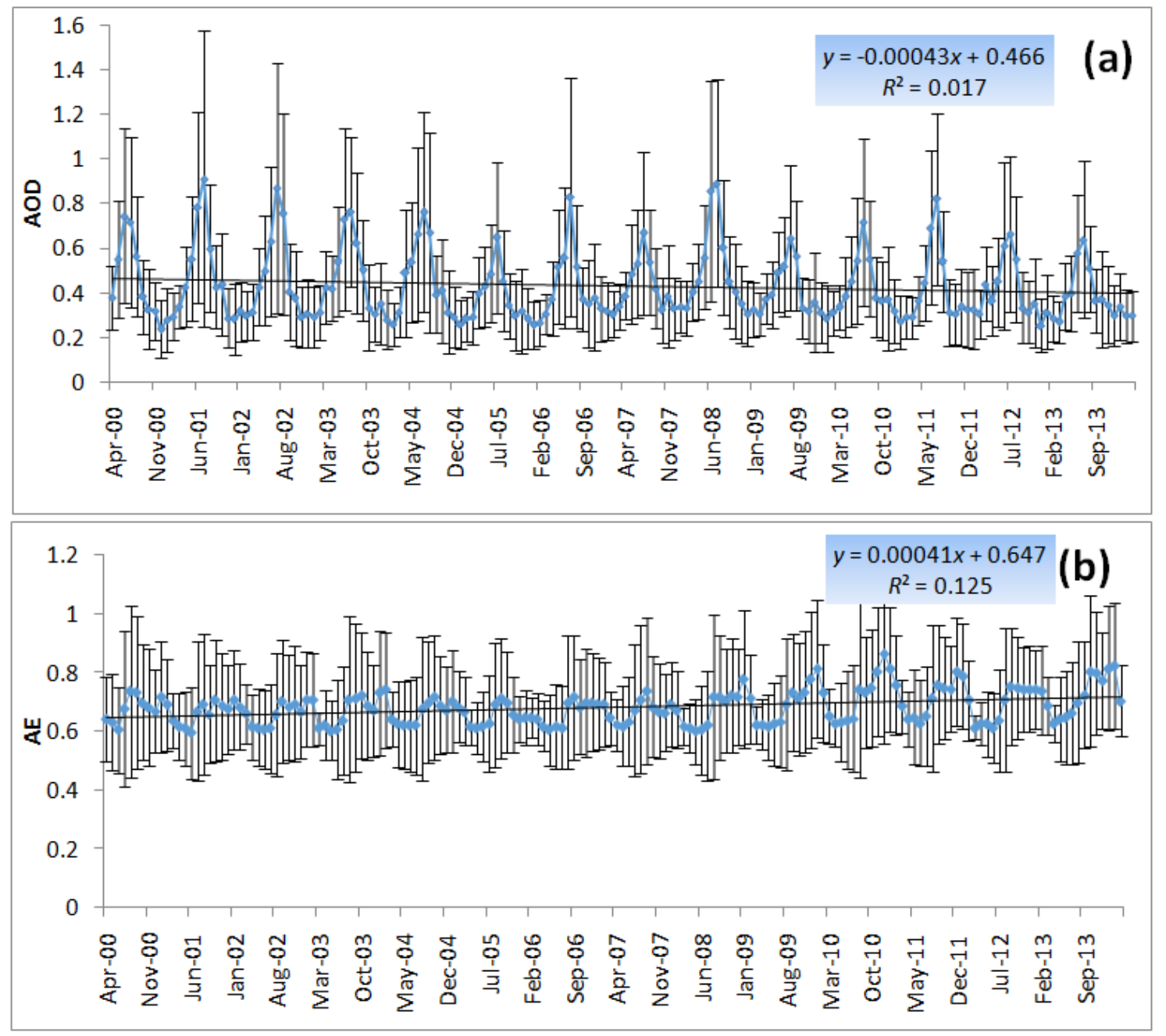



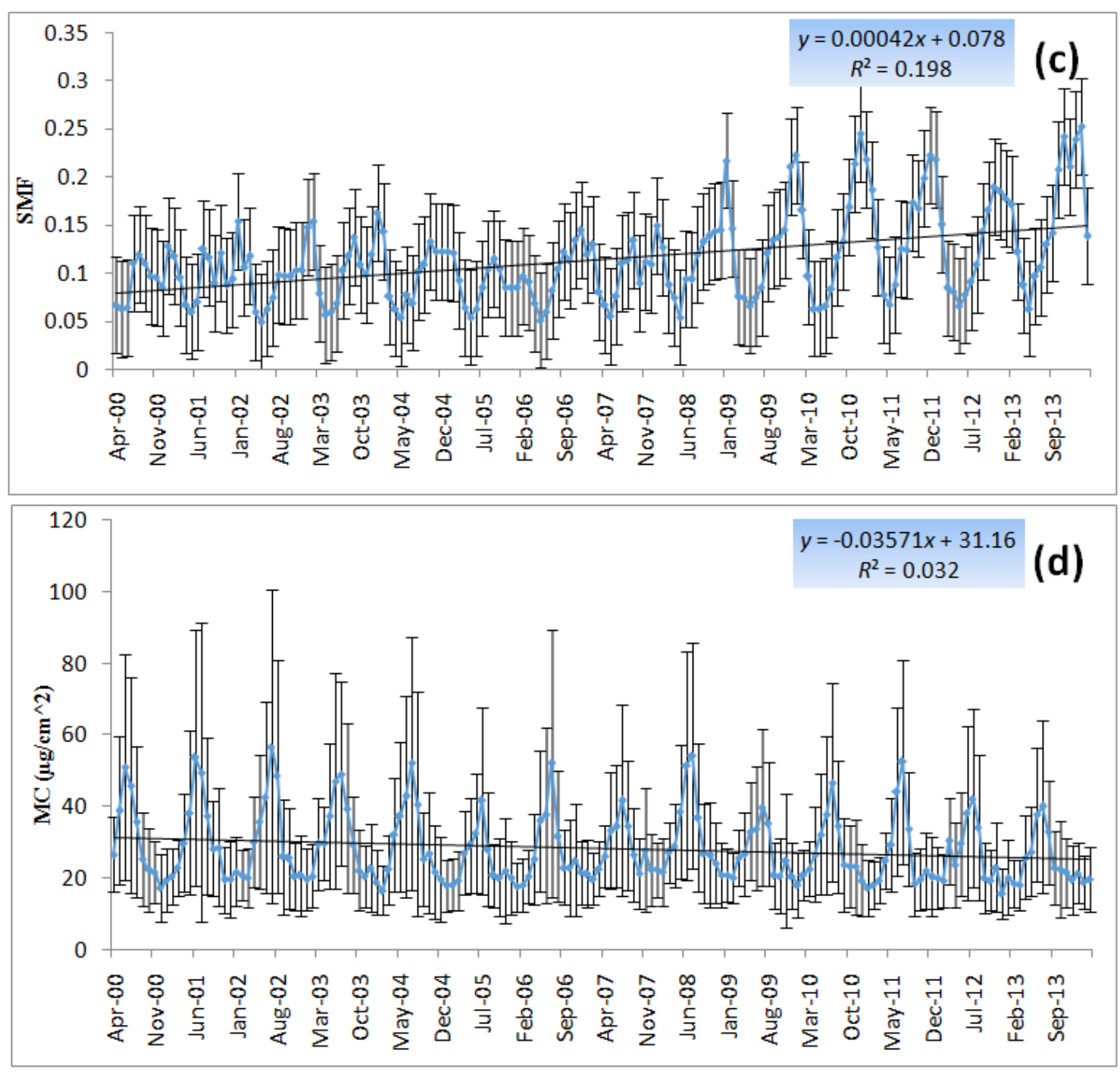

Figure 7. Time series of (a) AOD, (b) AE $E_{470-660,}$, (c) SMF and (d) MC derived from TerraMODIS over Pakistan during April 2000-March 2014. The error bars show standard deviations from the corresponding mean values

Extremely low mean value of $\mathrm{AE}_{470-660}$ signifies the dominance of coarse mode aerosols in the atmosphere of Pakistan during the study period. Figure $7 d$ shows time series of MC spatially averaged over Pakistan from April 2000 to March 2014. The MC values have been found to be ranging from $15.8 \mu \mathrm{g} / \mathrm{cm}^{2}$ to $56.6 \mu \mathrm{g} / \mathrm{cm}^{2}$ with an overall mean value of $28.2 \pm 9.71 \mu \mathrm{g} / \mathrm{cm}^{2}$. Like AOD, MC also shows a negative change $(-19.2 \%)$ with time. We find the highest value $\left(56.63 \mu \mathrm{g} / \mathrm{cm}^{2}\right)$ of MC in July 2002 and the lowest value $\left(15.76 \mu \mathrm{g} / \mathrm{cm}^{2}\right)$ in December 2012.

Figure $8 a-d$ shows the variations in monthly average values of AOD, AE $470-660, \mathrm{SMF}$ and MC derived from Terra-MODIS over Pakistan during April 2000-March 2014. Error bars represent the standard deviations from the mean values. It can be observed from Figure $8 a$ and $d$ that AOD and MC derived from Terra satellite have similar behaviors. Both AOD and MC have increased from January to their maximum values in July followed by a decrease to minimum values in December. The peak values of both Terra-AOD $(0.71 \pm 0.37)$ and MC $\left(43.36 \pm 26.8 \mu \mathrm{g} / \mathrm{cm}^{2}\right)$ have been found in July with 
corresponding values of $\mathrm{AE}_{470-660}$ and $\mathrm{SMF}$ to be $0.64 \pm 0.16$ and $0.09 \pm 0.02$ respectively. Elevated values of standard deviation for AOD and MC indicate that aerosols are highly variable in space. The lowest values of standard deviation for TerraAOD (0.09) and MC (6.7) are found in February indicating almost uniform distribution of aerosols over Pakistan. Our study is in agreement with the results from Alam et al. (2010) who showed that AOD increases from April, reaching its peak value in July and decreases afterwards to attain a minimum value in December. The increase of AOD in summer (June, July and August) is caused by dust transported from the Thar Desert (India) and Dasht Desert (Iran), sea-salt aerosols carried by strong south-westerly winds and increase in humidity within this region (Alam et al., 2010, 2011). Ranjan et al. (2007) analyzed the spectral variation of total column AOD over Rajkot (India) and they showed that water vapor content and AOD are proportional to each other, therefore, enhanced concentration of water vapor in summer results in higher AOD. Figure $8 b$ and $c$ show the variations of monthly averaged $\mathrm{AE}_{470-660}$ and $\mathrm{SMF}$ during the study period. It can be noted that both $\mathrm{AE}_{470-660}$ and $\mathrm{SMF}$ show a quite similar seasonal pattern. Both the parameters are found to be decreasing from January to attain their minimum values during May-June. Peak values of $\mathrm{AE}_{470-660}(0.73 \pm 0.18)$ and $\mathrm{SMF}$ $(0.16 \pm 0.05)$ are found in January. Relatively high values of standard deviation are linked to the higher fine mode aerosol concentration over northeastern Pakistan and lower over southern Pakistan. Low values of $\mathrm{AE}_{470-660}$ and $\mathrm{SMF}$ and their corresponding standard deviations during May-June are associated with dominance of desert dust aerosols over the entire Pakistan.

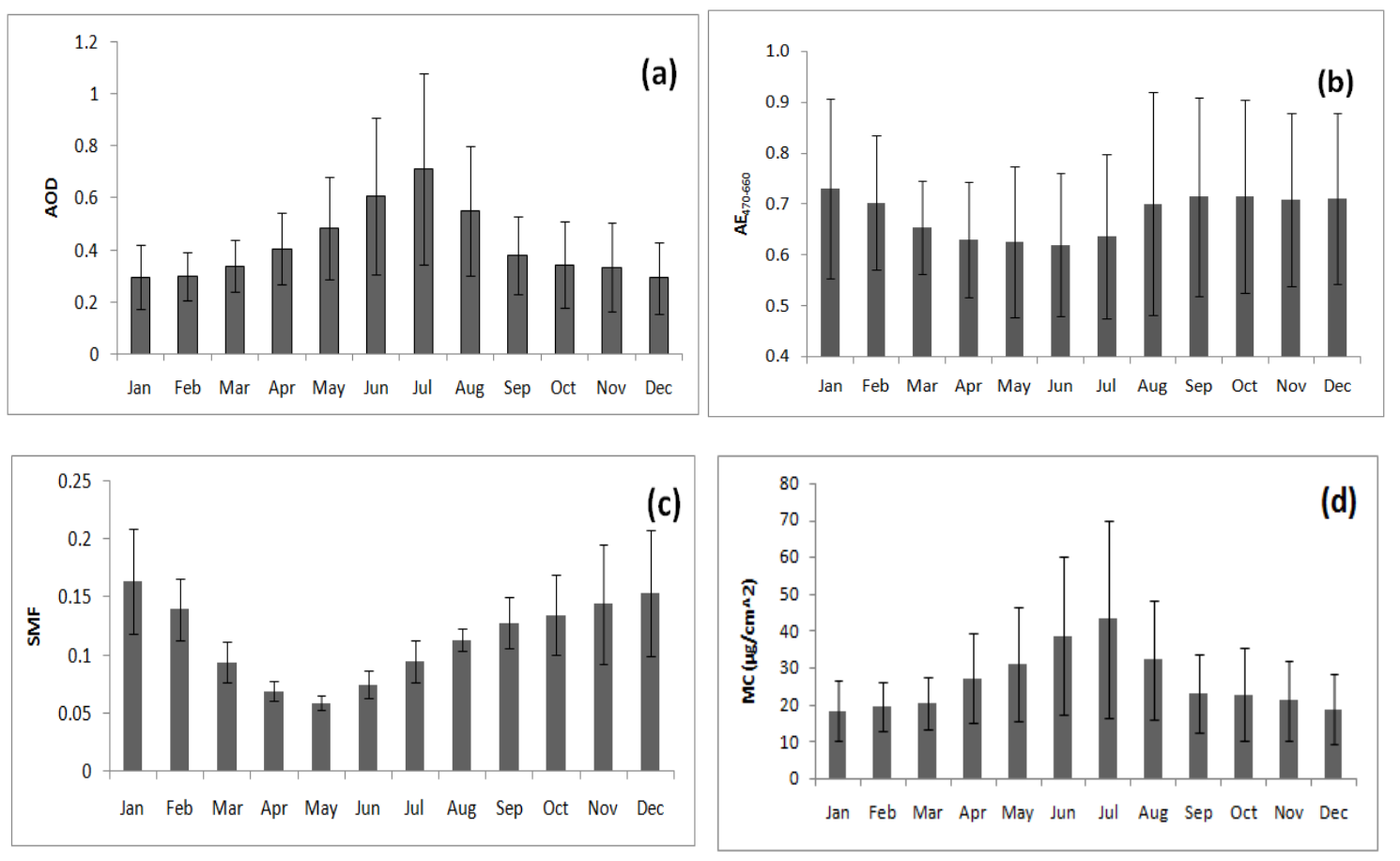

Figure 8. Temporal variations in monthly average values of (a) AOD, (b) $A E_{470-660,}$, (c) SMF and (d) MC derived from Terra-MODIS over Pakistan during April 2000-March 2014. The error bars show standard deviations from the corresponding mean values

Table 2 shows the linear trend parameters, correlation coefficients and relative changes (\%) per year of AOD, AE, SMF and MC on seasonal and annual basis over Pakistan. It can be observed from the table that slopes are negative for Terra-AOD 
during all the seasons except winter. AOD in summer showed the greatest declining trend of $-1.170 \%$ per year. The highest values of relative change per year of AOD $(0.325 \%)$ and $\mathrm{AE}(1.115 \%)$ are found during winter while the highest value of percentage change per year of SMF $(7.427 \%)$ is found during autumn. MC shows decreasing trend both on seasonal and annual basis. Significant (at 0.01 level) positive correlation is found for $\mathrm{AE}(r=0.775)$ and $\mathrm{SMF}(r=0.920)$ on mean annual data. Values of relative change per year are found to be negative for AOD (-0.615\%) and MC $(-0.986 \%)$, and positive for AE (0.570\%) and SMF (4.344\%).

Table 2. Linear trend parameters of equation of the form $a x+b$, where $a$ is slope and $b$ is $y$ intercept, of AOD, AE, SMF and MC over Pakistan. Correlation coefficient $(r)$ and relative change $(\%)$ per year are also given. $* *$ and $*$ represent correlation significance at the 0.01 and 0.05 levels (2-tailed) respectively

\begin{tabular}{c|c|c|c|c}
\hline & AOD & AE & SMF & MC \\
\hline \multirow{4}{*}{ Winter } & $\mathrm{a}=0.001$, & $\mathrm{a}=0.008$, & $\mathrm{a}=0.007$, & $\mathrm{a}=-0.037$, \\
& $\mathrm{b}=0.285$, & $\mathrm{b}=0.658$, & $\mathrm{b}=0.096$, & $\mathrm{b}=19.96$, \\
& $\mathrm{r}=0.366$, & $\mathrm{r}=0.741 * *$, & $\mathrm{r}=0.789 * *$, & $\mathrm{r}=-0.135$, \\
& $\Delta \mathrm{AOD}=0.325 \%$ & $\Delta \mathrm{AE}=1.115 \%$ & $\Delta \mathrm{SMF}=6.273 \%$ & $\Delta \mathrm{MC}=-0.172 \%$ \\
\hline \multirow{5}{*}{ Spring } & $\mathrm{a}=-0.004$, & $\mathrm{a}=0.001$, & $\mathrm{a}=0.001$, & $\mathrm{a}=-0.392$, \\
& $\mathrm{b}=0.445$, & $\mathrm{b}=0.618$, & $\mathrm{b}=0.064$, & $\mathrm{b}=31.00$, \\
& $\mathrm{r}=-0.619 *$, & $\mathrm{r}=0.521$, & $\mathrm{r}=0.634 *$ & $\mathrm{r}=-0.681^{* *}$, \\
& $\Delta \mathrm{AOD}=-0.842 \%$ & $\Delta \mathrm{AE}=0.150 \%$ & $\Delta \mathrm{SMF}=1.420 \%$ & $\Delta \mathrm{MC}=-1.189 \%$ \\
\hline \multirow{5}{*}{ Summer } & $\mathrm{a}=-0.009$, & $\mathrm{a}=0.001$, & $\mathrm{a}=0.001$, & $\mathrm{a}=-0.636$, \\
& $\mathrm{b}=0.723$, & $\mathrm{b}=0.645$, & $\mathrm{b}=0.085$, & $\mathrm{b}=46.44$, \\
& $\mathrm{r}=-0.487$, & $\mathrm{r}=0.371$, & $\mathrm{r}=0.453$, & $\mathrm{r}=-0.551^{*}$, \\
& $\Delta \mathrm{AOD}=-1.170 \%$ & $\Delta \mathrm{AE}=0.144 \%$ & $\Delta \mathrm{SMF}=1.073 \%$ & $\Delta \mathrm{MC}=-1.289 \%$ \\
\hline \multirow{5}{*}{ Autumn } & $\mathrm{a}=-0.001$, & $\mathrm{a}=0.006$, & $\mathrm{a}=0.007$, & $\mathrm{a}=-0.217$, \\
& $\mathrm{b}=0.368$, & $\mathrm{b}=0.673$, & $\mathrm{b}=0.080$, & $\mathrm{b}=24.82$, \\
& $\mathrm{r}=-0.244$, & $\mathrm{r}=0.850 * *$, & $\mathrm{r}=0.920 * *$, & $\mathrm{r}=-0.681^{*}$, \\
& $\Delta \mathrm{AOD}=-0.253 \%$ & $\Delta \mathrm{AE}=0.821 \%$ & $\Delta \mathrm{SMF}=7.427 \%$ & $\Delta \mathrm{MC}=-0.819 \%$ \\
\hline \multirow{5}{*}{ Annual } & $\mathrm{a}=-0.003$, & $\mathrm{a}=0.004$, & $\mathrm{a}=0.004$, & $\mathrm{a}=-0.321$, \\
& $\mathrm{b}=0.456$, & $\mathrm{b}=0.648$, & $\mathrm{b}=0.081$, & $\mathrm{b}=30.55$, \\
& $\mathrm{r}=-0.454$, & $\mathrm{r}=0.775 * *$, & $\mathrm{r}=0.873 * *$, & $\mathrm{r}=-0.623 *$, \\
& $\Delta \mathrm{AOD}=-0.615 \%$ & $\Delta \mathrm{AE}=0.570 \%$ & $\Delta \mathrm{SMF}=4.344 \%$ & $\Delta \mathrm{MC}=-0.986 \%$ \\
\hline
\end{tabular}

\section{Conclusions}

In the present study we have used Terra-MODIS data for the period April 2000March 2014 to analyze AOD $(550 \mathrm{~nm})$, Angstrom exponent ( $\left.\mathrm{AE}_{470-660}\right)$, small mode fraction (SMF) and mass concentration (MC) of aerosols over Pakistan. AOD from different satellite sensors have also been compared with ground-based AOD. Values of coefficient of determination $\left(R^{2}\right)$ between Terra-AOD and AERONET-AOD are found to be 0.718 and 0.745 for Lahore and Karachi respectively. Terra-AOD has also been compared with other satellite-based observations obtained from Aqua, MISR and SeaWiFS. We find significant correlations of Terra-AOD with Aqua-AOD $\left(R^{2}=0.968\right)$ and MISR-AOD $\left(R^{2}=0.919\right)$. A significant spatial variability in mean annual AOD values $(0.15-0.87)$ has been found with high values $(\sim 0.8)$ observed over northeastern and southern Pakistan. The $\mathrm{AE}_{470-660}$ amounts from 0.56 to 1.44 with high values (greater than 0.8 ) over northern Pakistan and relatively low values (less than 0.8 ) over 
southern Pakistan. Strong similarity in the spatial distributions of mean annual SMF and $\mathrm{AE}_{470-660}$ has been found. The $\mathrm{MC}$, ranging from 7.6-56.2 $\mu \mathrm{g} / \mathrm{cm}^{2}$, has spatial distribution quite similar to that of AOD. The latitudinal AOD shows peak values of $0.52,0.92,0.57$ and 0.47 during spring, summer, autumn and winter seasons, respectively, over latitude of $28.5^{\circ} \mathrm{N}$. A negative change $(-15.4 \%)$ in the AOD values is observed indicating a decrease in the total aerosol burden over Pakistan. However, a positive change (10.6\%) is observed in $\mathrm{AE}_{470-660}$ which indicates mounting contribution of fine mode aerosol particles towards total aerosol burden. The peak mean monthly values of both $\mathrm{AOD}(0.71)$ and $\mathrm{MC}\left(43.36 \mu \mathrm{g} / \mathrm{cm}^{2}\right)$ are observed in July with corresponding $\mathrm{AE}_{470-660}$ and SMF values of 0.64 and 0.09 , respectively. The overall mean values of the $\mathrm{AOD}, \mathrm{AE}_{470-660}, \mathrm{SMF}$ and $\mathrm{MC}$ are found to be $0.43 \pm 0.16$, $0.68 \pm 0.06,0.11 \pm 0.05$ and $28.2 \pm 9.71 \mu \mathrm{g} / \mathrm{cm}^{2}$ respectively. Trends and spatial distributions of different aerosol parameters discussed in this study are important in policy making for human health protection and environmental remediation. Furthermore, the assessment of aerosol concentrations presented in this study can be correlated with harmful effects on human health and drought indices, which can be a possible further research topic.

Acknowledgements. We are grateful to the MODIS, MISR, SeaWiFS and AERONET science teams and associated NASA personnel for data processing provided via GES-DISC. We are thankful to NOAA/OAR/ESRL PSD, Boulder, Colorado, USA, for providing NCEP-Reanalysis 2 data. We are also thankful to anonymous reviewer and editor for their useful comments to improve the original manuscript. This research project was funded by the University of the Punjab, Lahore, Pakistan.

\section{REFERENCES}

[1] Alam, K., Iqbal, M. J., Blaschke, T., Qureshi, S., Khan, G. (2010): Monitoring the spatiotemporal variations in aerosols and aerosol-cloud interactions over Pakistan using MODIS data. - Advances in Space Research 46: 1162-1176.

[2] Alam, K., Qureshi, S., Blaschke, T. (2011): Monitoring spatio-temporal aerosol patterns over Pakistan based on MODIS, TOMS and MISR satellite data and a HYSLPIT model. - Atmospheric Environment 45: 4641-4651.

[3] Alam, K., Sahar, N., Yaseen, I. (2014): Aerosol Characteristics and Radiative Forcing during Pre-Monsoon and Post-Monsoon Seasons in an Urban Environment. - Aerosol Air Quality and Research 14: 99-107.

[4] Ali, M., Tariq, S., Mahmood, K., Daud, A., Batool, A., Ul-Haq, Z. (2014): A study of aerosol properties over Lahore (Pakistan) by using AERONET data. - Asia-Pacific Journal of Atmospheric Science 50: 153-162.

[5] Angstrom, A. (1929): On the atmospheric transmission of sun radiation and on dust in the air. - Geograf. Ann. Deut. 11: 156-166.

[6] Arneth, A., Unger, N., Kulmala, M., Andreae, M. O. (2009): Clean the air, heat the planet. - Science 326: 672-673.

[7] Arneth, A. et al. (2010): Terrestrial biogeochemical feedbacks in the climate system. Nature Geoscience 3: 525-532.

[8] Bellouin, N., Boucher, O., Haywood, J., Reddy, M. S. (2005): Global estimate of aerosol direct radiative forcing from satellite measurements. - Nature 438: 1138-1141.

[9] Bennouna, Y. S., Cachorro, V. E., Torres, B., Toledano, C., Berjon, A., de Frutos, A. M., Coppel, I. A. F. (2013): Atmospheric turbidity determined by the annual cycle of the aerosol optical depth over north-center Spain from ground (AERONET) and satellite (MODIS). - Atmospheric Environment 67: 352-364. 
[10] Bibi, H., Alam, K., Chishtie, F., Bibi, S., Shahid, I., Blaschke, T. (2015): Intercomparison of MODIS, MISR, OMI, and CALIPSO aerosol optical depth retrievals for four locations on the Indo-Gangetic plain and validation against AERONET data. - Atmospheric Environment 111: 113-126.

[11] Biswas, K. F., Ghauri, B. M., Husain, L. (2008): Gaseous and aerosol pollutants during fog and clear episodes in South Asian urban atmosphere. - Atmospheric Environment 42: 7775-7785.

[12] Carslaw, K. S. et al. (2010): A review of natural aerosol interactions and feedbacks within the Earth system. - Atmospheric Chemistry and Physics 10: 1701-1737.

[13] Charlson, R. J., Schwartz, S. E., Hales, J. M., Cess, R. D., Coakley, J. A., Hansen, J. E., Hofmann, D. J. (1992): Climate forcing by anthropogenic aerosols. - Science 255: 423430.

[14] Chu, D., Kaufman, Y., Ichoku, C., Remer, L., Tanré, D., Holben, B. (2002): Validation of MODIS aerosol optical depth retrieval over land. - Geophysical Research Letters 29: 1-4 (MOD 2).

[15] Chu, D. A., Kaufman, Y. J., Zibordi, G., Chern, J. D., Mao, J., Li, C., Holben, B. N. (2003): Global monitoring air pollution over land from the earth observing systemterra moderate resolution imaging Spectroradiometer (MODIS). - Journal of Geophysical Research 108: D21. http://dx.doi.org/10.1029/2002JD003179.

[16] Dani, K. K., Raj, P. E., Devara, P. C. S., Pandithurai, G., Sonbawne, S. M., Maheskumar, R. S., Saha, S. K., Rao, Y. J. (2012): Long-term trends and variability in measured multispectral aerosol optical depth over a tropical urban station in India. - International Journal of Climatology 32: 153-160.

[17] Diner, D. J., Beckert, J. C., Reilly, T. H., Bruegge, C. J., Conel, J. E., Kahn, R. A., Martonchik, J. V., Ackerman, T. P., Davies, R., Gerstl, S. A. W., Gordon, H. R., Muller, J., Myneni, R. B., Sellers, P. J., Pinty, B., Verstraete, M. M. (1998): Multiangle Imaging Spectroradiometer (MISR) description and experiment overview. - IEEE Transactions on Geoscience and Remote Sensing 36: 1072-1087.

[18] Diner, D. J., Abdou, W. A., Bruegge, C. J., Conel, J. E., Crean, K. A., Gaitley, B. J., Helmlinger, M., Kahn, R. A., Martonchik, J. V., Pilorz, S. H. (2001): MISR aerosol optical depth retrievals over southern Africa during the SAFARI-2000 dry season campaign. - Geophysical Research Letters 28: 3127-3130.

[19] Dubovik, O., King, M. D. (2000): A flexible inversion algorithm for retrieval of aerosol optical properties from sun and sky radiance measurements. - Journal of Geophysical Research 105(20): 673-696.

[20] Eck, T., Holben, B. N., Reid, J., Dubovik, O., Smirnov, A., O’Neill, N., Slutsker, Kinne, I., S. (1999): Wavelength dependence of the optical depth of biomass burning, urban, and desert dust aerosols. - Journal of Geophysical Research 104(D24): 31333-31349.

[21] Eck, T. F., Holben, B. N., Ward, D. E., Dubovik, O., Reid, J. S., Smirnov, A., Mukelavi, M. M., Hsu, N. C., O’Neill, N. T., Slutsker, I. (2001): Characterization of the optical properties of biomass burning aerosols in Zambia during the 1997 ZIBBEE field campaign. - Journal of Geophysical Research 106: 3425-3448.

[22] Eplee Jr., R. E., Meister, G., Patt, F. S., Franz, B. A., McClain, C. R. (2011): Uncertainty Assessment of the SeaWiFS On-Orbit Calibration. - In: Butler, J. J., Xiong, X., Gu, X. (eds). Earth Observing Systems, Vol. 8153. Proc. SPIE 8153. DOI: 10.1117/12.892340.

[23] Forster, P. et al. (2007): Changes in Atmospheric Constituents and in Radiative Forcing. - In: Solomon, S. et al. (eds.) - Climate Change 2007: The Physical Science Basis, pp. 129-234. Cambridge Univ. Press, Cambridge.

[24] Ghauri, B., Manzar, S., Mirza, M. I. (1994): An assessment of air quality in Karachi, Pakistan. - Environmental Monitoring and Assessment 32: 37-45.

[25] Gupta, P., Khan, M. N., da Silva, A., Patadia, F. (2013): MODIS aerosol optical depth observations over urban areas in Pakistan: Quantity and quality of the data for air quality monitoring. - Atmospheric Pollution Research 4: 43-52. 
[26] He, Q., Li, C., Geng, F., Lei, Y., Li, Y. (2012): Study on long-term aerosol distribution over the land of East China using MODIS data. - Aerosol and Air Quality Research 12: 304-319.

[27] Holben, B. N., Eck, T. F., Slutsker, I., Tanré, D., Buis, J. P., Setzer, A., Vermote, E., Reagan, J. A., Kaufman, Y. J., Nakajima, T., Lavenu, F., Jankowiak, I., Smirnov, A. (1998): AERONET-A federated instrument network and data archive for aerosol characterization. - Remote Sensing of Environment 66: 1-16.

[28] Hsu, N. C., Tsay, S. C., King, M. D., Herman, J. R. (2004): Aerosol properties over bright reflecting source regions. - IEEE Transactions on Geoscience and Remote Sensing 42: 557-569.

[29] Hsu, N. C., Tsay, S. C., King, M. D., Herman, J. R. (2006): Deep blue retrievals of Asian aerosol properties during ACE-Asia. - IEEE Transactions on Geoscience and Remote Sensing 44: 3180-3195.

[30] Hyer, E., Reid, J., Zhang, J. (2011): An over-land aerosol optical depth data set for data assimilation by filtering, correction, and aggregation of MODIS Collection 5 optical depth retrievals. - Atmospheric Measurement Techniques 4: 379-408.

[31] IPCC (2007): Climate Change 2007: The Physical Science Basis. - In: Solomons, S., Qin, D., Manning, M., Chen, Z., Marquis, M., Averyt, K. B., Tignor, M., Miller, H. L. (eds.) Contribution of Working Group I to the Fourth Assessment Report of the IPCC. Cambridge University Press, Cambridge.

[32] Jacobson, M. Z. (2001): Strong radiative heating due to the mixing state of black carbon in atmospheric aerosols. - Nature 409: 695-698.

[33] Kahn, R. A., Gaitley, B., Martonchik, J., Diner, D. J., Crean, K., Holben, B. N. (2005): MISR global aerosol optical depth validation based on two years of coincident AERONET observations. - Journal of Geophysical Research 110: D10S04. http://dx.doi.org/10.1029/2004JD004706.

[34] Kahn, R. A., Gaitley, B. J., Garay, M. J., Diner, D. J., Eck, T. F., Smirnov, A., Holben, B. N. (2010): Multiangle imaging spectroradiometer global aerosol product assessment by comparison with the aerosol robotic network. - Journal of Geophysical Research 115(D23). http://dx.doi.org/10.1029/2010JD014601.

[35] Kalapureddy, M. C. R., Devara, P. C. S. (2008): Characterization of aerosols over oceanic regions around India during pre-monsoon. - Atmospheric Environment 42: 6816-6827.

[36] Kaskaoustis, D. G., Kambezidis, H. D., Hatzianastassiou, N., Kosmopoulos, P. G., Badarinath, V. S. (2007): Aerosol climatology: on the discrimination of aerosol types over four AERONET sites. - Atmospheric Chemistry and Physics 7: 6357-6411.

[37] Kaufman, Y. J., Tanré, D., Remer, L. A., Vermote, E. F., Chu, A., Holben, B. N. (1997): Operational remote sensing of tropospheric aerosol over land from EOS moderate resolution imaging Spectroradiometer. - Journal of Geophysical Research 102: 1705117067.

[38] Kaufman, Y. J., Boucher, O., Tanré, D., Chin, M., Remer, L. A., Takemura, T. (2005a): Aerosol anthropogenic component estimated from satellite data. - Geophysical Research Letters 32: L17804. DOI: 10.1029/2005GL023125.

[39] Kaufman, Y. J., Koren, I., Remer, L. A., Tanré, D., Ginoux, P., Fan, S. (2005b): Dust transport and deposition observed from the Terra-Moderate Resolution Imaging Spectroradiometer (MODIS) spacecraft over the Atlantic Ocean. - Journal of Geophysical Research 110: D10S12. DOI: 10.1029/2003JD004436.

[40] Kedia, S., Ramachandran, S. (2009): Variability in aerosol optical and physical characteristics over the Bay of Bengal and the Arabian Sea deduced from Angstrom exponents. - Journal of Geophysical Research 114: D14207.

[41] King, M. D., Kaufman, Y. J., Menzel, W. P., Tanré, D. (1992): Remote-sensing of cloud, aerosol, and water-vapor properties from the Moderate Resolution Imaging Spectrometer (MODIS). - IEEE Transactions on Geoscience and Remote Sensing 30: 2-27. 
[42] Kosmopoulos, P. G., Kaskaoutis, D. G., Nastos, P. T., Kambezidis, H. D. (2008): Seasonal variation of columnar aerosol optical properties over Athens, Greece, based on MODIS data. - Remote Sensing of Environment 112: 2354-2366.

[43] Koukouli, M. E., Kazadzis, S., Amiridis, V., Ichoku, C., Balis, D. S., Bais, A. F. (2010): Signs of a negative trend in the MODIS aerosol optical depth over the Southern Balkans. - Atmospheric Environment 44: 1219-1228.

[44] Kumar, S., Kumar, S., Singh, A. K., Singh, R. P. (2012): Seasonal variability of atmospheric aerosol over the North Indian region during 2005-2009. - Journal of Advances in Space Research 50: 1220-1230.

[45] Kumar, K. R., Yin, Y., Sivakumar, V., Kang, N., Yu, X., Diao, Y., Adesina, A. J., Reddy, R. R. (2015): Aerosol climatology and discrimination of aerosol types retrieved from MODIS, MISR, and OMI over Durban $\left(29.88^{\circ} \mathrm{S}, 31.02^{\circ} \mathrm{E}\right)$, South Africa. - Atmospheric Environment 117: 9-18.

[46] Levy, R. C., Remer, L. A., Dubovik, O. (2007): Global aerosol optical properties and application of Moderate Resolution Imaging Spectroradiometer aerosol retrieval over land. - Journal of Geophysical Research 11: D13210.

[47] Levy, R. C., Remer, L. A., Kleidman, R. G., Mattoo, S., Ichoku, C., Kahn, R., Eck, T. F. (2010): Global evaluation of the collection 5 MODIS dark-target aerosol products over land. - Atmospheric Chemistry and Physics Discussions 10: 14815-14873.

[48] Lohmann, U., Feichter, J. (2005): Global indirect aerosol effects: A review. Atmospheric Chemistry and Physics 5: 715-737.

[49] Luo, Y., Zheng, X., Zhao, T., Chen, J. (2014): A climatology of aerosol optical depth over China from recent 10 year of MODIS remote sensing data. - International Journal of Climatology 34: 863-870.

[50] Mahowald, N. (2011): Aerosol indirect effects on biogeochemical cycles and climate. Science 334: 794-796.

[51] Makkonen, R. et al. (2012): Air pollution control and decreasing new particle formation lead to strong climate warming. - Atmospheric Chemistry and Physics 12: 1515-1524.

[52] Martonchik, J. V., Diner, D. J., Kahn, R. A., Ackerman, T. P., Verstraete, M. M., Pinty, B., Gordon, H. R. (1998): Techniques for the retrieval of aerosol properties over land and ocean using multiangle imaging, - IEEE Transactions on Geoscience and Remote Sensing 36: 1212-1227.

[53] Mickley, L. J., Leibensperger, E. M., Jacob, D. J., Rind, D. (2012): Regional warming from aerosol removal over the United States: Results from a transient 2010-2050 climate simulation. - Atmospheric Environment 46: 545-553.

[54] Middleton, N. J. (1986): Geography of dust storms in southwest Asia. - Journal of Climatology 6: 183-196.

[55] O’Neill, N. T., Eck, T. F., Holben, B. N., Smirnov, A., Dubovik, O., and Royer, A. (2001): Bimodal size distribution influences on the variation of Angstrom derivatives in spectral and optical depth space. - Journal of Geophysical Research 106: 9787-9806.

[56] Penner, J. E., Zhang, S. Y., Chuang, C. C. (2003): Soot and smoke may not warm climate. - Journal of Geophysical Research 108: D21. DOI: 10.1029/2003JD003409.

[57] Petrenko, M., Ichoku, C., Leptoukh, G. (2012): Multi-sensor aerosol products sampling system (mapss). - Atmospheric Measurement Techniques 5: 913-926.

[58] Prasad, A. K., Singh, R. P. (2007): Comparison of MISR-MODIS aerosol optical depth over the Indo-Gangetic basin during the winter and summer seasons (2000-2005). Remote Sensing of Environment 107: 109-119.

[59] Prasad, A. K., Singh, R. P., Singh, A. (2006): A seasonal climatology of aerosol optical depth over the Indian subcontinent: trend and departures in recent years. - International Journal of Remote Sensing 27: 2323-2329.

[60] Prasad, A. K., Singh, S., Chauhan, S. S., Srivastava, M. K., Singh, R. P., Singh, R. (2007): Aerosol radiative forcing over the Indo-Gangetic plains during major dust storms. - Atmospheric Environment 41: 6289-6301. 
[61] Prospero, J. M., Ginoux, P., Torres, O., Nicholson, S. E., Gill, T. E. (2002): Environmental characterization global sources of atmospheric soil dust identified with the Nimbus 7 total ozone mapping spectrometer (TOMS) absorbing aerosol product. - Rev. Geophys. 40: 1002.

[62] Qureshi, S. (2010): The fast growing megacity Karachi as a frontier of environmental challenges: urbanization and contemporary urbanism issues. - J. Geogr. Reg. Plan. 3: 306-321.

[63] Raja, S., K. F. Biswas, L. Husain, Hopke, P. K. (2010): Source apportionment of the atmospheric aerosol in Lahore, Pakistan. - Water Air Soil Pollut. 208: 43-57.

[64] Ramanathan, V., Crutzen, P. J., Kiehl, J. T., Rosenfeld, D. (2001): Aerosol, climate, and hydrological cycle. - Science 294: 2119-2124.

[65] Ranjan, R. R., Joshi, H. P., Iyer, K. N. (2007): Spectral variation of total column aerosol optical depth over Rajkot: A tropical semi-arid Indian station. - Aerosol Air Quality and Reseach 7: 33-45.

[66] Remer, L. A., Kaufman, Y. J., Tanré, D., Mattoo, S., Chu, D. A., Martins, J. V., Li, R., Ichoku, C., Levy, R. C., Kleidman, R. G., Eck, T. F., Vermote, E., Holben, B. N. (2005): The MODIS aerosol algorithm, products and validation. - Journal of Atmospheric Science 62: 947-973.

[67] Schuster, G. L., Dubovik, O., Holben, B. N. (2006): Angstrom Exponent and Bimodal Aerosol Size Distributions. - Journal of Geophysics Research 111: D07207.

[68] Singh, RP, Dey S, Tripathi, SN, Tare V, Holben, B. (2004): Variability of aerosol parameters over Kanpur, northern India. - Journal of Geophysics Research 109: D23206. http://dx.doi.org/10.1029/2004JD004966.

[69] Smart, J. C. R., Hicks, K., Morrissey, T., Heinemeyer, A., Sutton, M. A., Ashmore, M. (2011): Applying the ecosystem service concept to air quality management in the UK: A case study for ammonia. - Environmetrics 22(5). DOI: 10.1002/env.1094.

[70] Sokolik, I., N., O., B., Toon (1996): Radiative forcing by anthropogenic mineral aerosols, - Nature 381: 681-683.

[71] Sreekanth, V. (2013): Satellite derived aerosol optical depth climatology over Bangalore, India. - Advances in Space Research 51: 2297-2308.

[72] Tanré, D., Kaufman, Y. J., Herman, M., Mattoo, S. (1997): Remote sensing of aerosol properties over oceans using the MODIS/EOS spectral radiances. - Journal of Geophysical Research 102: (D14), D1416.

[73] Tariq, S., Ali, M. (2015): Spatio-temporal Distribution of Absorbing Aerosols over Pakistan Retrieved from OMI Onboard Aura Satellite. - Atmospheric Pollution Research 6: 254-266.

[74] Tariq, S., ul-Haq, Z., Ali, M. (2015): Analysis of optical and physical properties of aerosols during crop residue burning event of October 2010 over Lahore, Pakistan. Atmospheric Pollution Research 6: 969-978.

[75] Tariq, S., ul-Haq, Z., Ali, M. (2016): Satellite and ground-based remote sensing of aerosols during intense haze event of October 2013 over Lahore, Pakistan. - Asia-Pacific Journal of Atmospheric Science 52: 25-33.

[76] Tariq, S. (2017). A Study on the Spatio-temporal Distribution, Properties and Transport of Atmospheric Aerosols over the Pakistan using Remote Sensing. Ph.D. Thesis.

[77] Tripathi, S., Dey, S., Chandel, A., Srivastava, S., Singh, R. P., Holben, B. (2005): Comparison of MODIS and AERONET derived aerosol optical depth over the Ganga Basin India. - Ann. Geophys. 23: 1093-1101.

[78] ul-Haq, Z., Tariq, S., Rana, A. D., Ali, M., Mahmood, K., Shahid, P. (2015a): Satellite remote sensing of total ozone column (TOC) over Pakistan and neighbouring regions. International Journal of Remote Sensing 36: 1038-1054.

[79] ul-Haq, Z., Rana, A. D., Ali, M., Mahmood, K., Tariq, S., Qayyum, Z. (2015b): Carbon monoxide $(\mathrm{CO})$ emissions and its tropospheric variability over Pakistan using satellitesensed data. - Advances in Space Research 56: 583-595. 
[80] ul-Haq, Z., Tariq, S., Ali, M. (2016): Spatiotemporal patterns of correlation between atmospheric nitrogen dioxide and aerosols over South Asia. - Meteorology and Atmospheric Physics 129(5): 507-527. DOI: 10.1007/s00703-016-0485-6.

[81] ul-Haq, Z., Tariq, S., Ali, M. (2017): Spatiotemporal assessment of $\mathrm{CO}_{2}$ emissions and its satellite remote sensing over Pakistan and neighboring regions. - Journal of Atmospheric and Solar-Terrestrial Physics 152: 11-19.

[82] Wang, J., Christopher, S. A. (2003): Intercomparison between satellite-derived aerosol optical thickness and PM2.5 mass: implications for air quality studies. - Geophysical Research Letters 30(21). DOI: 10.1029/2003GL018174.

[83] Westphal, D., Toon, O. (1991): Simulations of microphysical, radiative, and dynamical processes in a continental-scale forest fire smoke plume. - Journal of Geophysical Research 96(D12): 22379-22400.

[84] Xiao, N., Shi, T., Calder, C. A., Munroe, D. K., Berrett, C., Wolfinbarger, S., Li, D. (2009): Spatial characteristics of the difference between MISR and MODIS aerosol optical depth retrievals over mainland Southeast Asia. - Remote Sensing of Environment 113: $1-9$. 